\title{
Dokumentenverzeichnis / Wykaz dokumentów
}

001

20.12.1920: Regierungsrat Dr. Poeschel in Königsberg. Aufzeichnung über eine Fahrt durch das Abstimmungsgebiet (13.-18.12.1920)

20 XII 1920r.: Radca rządowy dr Poeschel w Königsberg. Notatka z podróży po obszarze plebiscytowym (13-18 XII 1920r.)

002

5.4.1921: Landesgrenzpolizei in Königsberg an das Preußische Ministerium des Innern. Sekretär des Polenbundes in Allenstein, Bruno Gabrylewicz

5 IV 192 lr.: Krajowa policja graniczna w Königsberg do MSW Prus.Bruno Gabrylewicz, sekretarz Związku Polaków w Allenstein

003

28.2.1922: Landeskriminalpolizei in Königsberg an das PreuBische Ministerium des Innern. Stand der polnischen Bewegung in den ehemaligen Abstimmungsgebieten

28 II 1922r.: Krajowa policja kryminalna w Königsberg do MSW Prus. Stan ruchu polskiego na byłych obszarach plebiscytowych

004

10.6.1922: Landeskriminalpolizei in Königsberg an das Preußische Ministerium des Innern. Republik Polen und polnische Minderheit

10 VI 1922r.: Krajowa policja kryminalna w Königsberg do MSW Prus. Rzeczpospolita Polska a mniejszość polska

005

August 1922: Der Oberpräsident in Königsberg an den Staatskommissar für öffentliche Ordnung. Versammlung des polnischen Schulvereins in Stuhm (30.7.1922)

Sierpień 1922r.: Naczelny prezydent w Königsberg do komisarza państwowego d/s porządku publicznego. Zebranie towarzystwa szkolnego w Stuhm (30 VII 1922r.)

006

8.11.1922: Landeskriminalpolizei in Königsberg an das Preußische Ministerium des Innern. Entwicklung der polnischen Bewegung seit dem Plebiszit

18 XI 1922r.: Krajowa policja kryminalna w Königsberg do MSW Prus. Rozwój ruchu polskiego od czasu plebiscytu

007

15.11.1922: Der Oberpräsident in Königsberg an den Staatskommissar für öffentliche Ordnung. Lagebericht (1.-15.11.1922)

15 XI 1922r.: Naczelny prezydent w Königsberg do komisarza państwowego d/s porządku publicznego. Sprawozdanie sytuacyjne (1-15 XI 1922r.) 
008

8.1.1923: Der Oberpräsident in Königsberg an den Präsidenten des Landesfinanzamtes ebendort. Deutsche Beamte auf einer polnischen Festveranstaltung in Stuhm (22.10.1922)

8 I 1923r.: Naczelny prezydent w Königsberg do prezydenta krajowego urzędu skarbowego w miejscu. Udział urzędników niemieckich w uroczystości polskiej w Stuhm (22 X 1922r.)

\section{9}

30.1.1923: Landeskriminalpolizei in Königsberg an den Staatskommissar für öffentliche Ordnung. Mögliche Besetzung Ostpreußens durch Polen

30 I 1923r.: Krajowa policja kryminalna w Königsberg do komisarza państwowego d/s porządku publicznego. Możliwość okupacji Prus Wschodnich przez Polskę

010

22.5.1923: Landeskriminalpolizei in Königsberg an den Staatskommissar für öffentliche Ordnung. Errichtung polnischer Ein- und Verkaufsstellen für Getreide und Kunstdünger 22 V 1923r.: Krajowa policja kryminalna w Königsberg do komisarza państwowego $\mathrm{d} / \mathrm{s}$ porządku publicznego. Utworzenie polskich punktów skupu i sprzedaży zboża i nawozów sztucznych

\section{1}

24.5.1923: Landeskriminalpolizei in Königsberg an den Staatskommissar für öffentliche Ordnung. Intervention polnischer Minderheitenführer zugunsten verurteilter Redakteure der ,Deutschen Rundschau in Polen“

24 V 1923: Krajowa policja kryminalna w Königsberg do komisarza państwowego d/s porządku publicznego. Interwencja przywódców mniejszości polskiej na rzecz skazanych redaktorów dziennika „Deutsche Rundschau in Polen“

\section{2}

28.5.1923: Landeskriminalpolizei in Königsberg an den Staatskommissar für öffentliche Ordnung. Verlagerung des Schwerpunktes der polnischen Bewegung - 28.5.1923

$28 \mathrm{~V}$ 1923r.: Krajowa policja kryminalna w Königsberg do komisarza państwowego d/s porządku publicznego. Przesunięcie punktu ciężkości ruchu polskiego

013

9.6.1923: Landeskriminalpolizei in Königsberg an den Staatskommissar für öffentliche Ordnung. Zunehmendes Selbstbewußtsein der polnischen Minderheit

9 VI 1923r.: Krajowa policja kryminalna w Königsberg do komisarza państwowego d/s porządku publicznego. Rosnąca pewność siebie mniejszości polskiej

\section{4}

16.8.1923: Landeskriminalpolizei in Königsberg an den Staatskommissar für öffentliche Ordnung. Gründungsversuch einer polnischen landwirtschaftlichen Genossenschaft in Stuhm (Frühjahr 1923)

16 VIII 1923r.: Krajowa policja kryminalna w Königsberg do komisarza państwowego $\mathrm{d} / \mathrm{s}$ porządku publicznego. Próba założenia polskiej spółdzielni rolniczej w Stuhm (wiosna 1923r.) 


\section{5}

4.11.1923: Der Oberpräsident in Königsberg an den Staatskommissar für öffentliche Ordnung. Lagebericht (16. - 31. Oktober 1923)

4 XI 1923r.: Naczelny prezydent w Königsberg do komisarza państwowego d/s porządku publicznego. Sprawozdanie sytuacyjne (16-31 X 1923r.)

016

November 1923: Der Oberpräsident in Königsberg an den Staatskommissar für öffentliche Ordnung. Engagement des Sanitätsrates Dr. Morawski, Stuhm, in der polnischen Bewegung

Listopad 1923r.: Naczelny prezydent w Königsberg do komisarza państwowego d/s porządku publicznego. Angażowanie się radcy sanitarnego dra Morawskiego w Stuhm w ruch polski

017

24.5.1924: Landesgrenzpolizei in Königsberg an den Oberpräsidenten ebendort. Gemeindewahlen in Straszewo, Kreis Stuhm

24 V 1924r.: Krajowa policja graniczna w Königsberg do naczelnego prezydenta w miejscu. Wybory gminne we wsi Straszewo, pow. Stuhm

\section{8}

24.1.1925: Der Oberpräsident in Königsberg an den PreuBischen Minister für Wissenschaft, Kunst und Volksbildung. Gründung eines Verbandes der polnischen Jugendvereine Ostpreußens in Allenstein (3.11.1923)

24 I 1925r.: Naczelny prezydent w Königsberg do pruskiego ministra nauki, sztuki i oświaty ludowej publicznej. Zalożenie Związku Polskich Stowarzyszeń Młodzieżowych Prus Wschodnich w Allenstein (3 XI 1923r.)

\section{9}

10.9.1925: Landesgrenzpolizei in Königsberg an das PreuBische Ministerium des Innern. Unzufriedenheit der polnischen Minderheit im Kreis Stuhm mit ihren Führern 10 IX 1925r.: Krajowa policja graniczna w Königsberg do MSW Prus. Niezadowolenie mniejszości polskiej w powiecie Stuhm z jej przywódców

\section{0}

14.10.1925: Landesgrenzpolizei in Königsberg an das Preußische Ministerium des Innern. Zusammenarbeit von polnischer und litauischer Minderheit in Deutschland 14 X 1925r.: Krajowa policja graniczna w Königsberg do MSW Prus. Współpraca mniejszości polskiej i litewskiej w Niemczech

\section{1}

5.12.1925: Landesgrenzpolizei in Königsberg an das Preußische Ministerium des Innern. Gerüchte über eine Besetzung Ostpreußens durch Polen

5 XII 1925r.: Krajowa policja graniczna w Königsberg do MSW Prus. Pogłoski o okupacji Prus Wschodnich przez Polske 
022

5.12.1925: Landesgrenzpolizei in Königsberg an das Preußische Ministerium des Innern. Beurteilung der Familie des Kaufmanns Block, Stuhm, in nationaler Hinsicht

5 XII 1925r: Krajowa policja graniczna w Königsberg do MSW Prus. Opinia na temat rodziny kupca Emila Blocka, zam. w Stuhm, pod względem narodowym

\section{3}

6.1.1926: Landesgrenzpolizei in Königsberg an das Preußische Ministerium des Innern. Das polnische Bankwesen

6 I 1926r.: Krajowa policja graniczna w Königsberg do MSW Prus. Polski system bankowy

\section{4}

11.1.1926: Landesgrenzpolizei in Königsberg an das Preußische Ministerium des Innern. Finanzkrise der polnischen Bewegung

11 I 1926r.: Krajowa policja graniczna w Königsberg do MSW Prus. Kryzys finansowy ruchu polskiego

\section{5}

26.9.1929: Der Oberpräsident in Königsberg an das Preußische Ministerium des Innern. Polnische Fahnen beim Schulfest der Minderheitsschule in Honigfelde (14.9.1929)

26 IX 1929r.: Naczelny prezydent w Königsberg do MSW Prus. Flagi polskie na uroczystości szkolnej szkoły mniejszości polskiej we wsi Honigfelde (14 IX 1929r.)

\section{6}

11.10.1934: Der Oberpräsident in Königsberg an das Preußische Ministerium des Innern. Lagebericht (September 1934)

11 X 1934r.: Naczelny prezydent w Königsberg do MSW Prus. Sprawozdanie sytuacyjne (wrzesień 1934r.)

\section{7}

7.11.1934: Staatspolizeistelle Königsberg an das Geheime Staatspolizeiamt. Lagebericht (Oktober 1934)

7 XI 1934r.: Placówka policji państwowej w Königsberg do urzędu tajnej policji państwowej. Sprawozdanie sytuacyjne (październik 1934r.)

028

18.5.1935: Der Oberpräsident in Königsberg an den Reichs- und Preußischen Minister des Innern. Lagebericht (März-April 1935)

18 V 1935r.: Naczelny prezydent w Königsberg do ministra spraw wewnętrznych Rzeszy i Prus. Sprawozdanie sytuacyjne (marzec-kwiecień 1935r.)

029

19.11.1920: Der Landrat in Stuhm an den Regierungspräsidenten in Marienwerder. Polnische Kindergärten

19 XI 1920r.: Landrat w Stuhm do prezydenta rejencji w Marienwerder. Przedszkola polskie 
030

19.3.1922: Der Regierungspräsident in Marienwerder an den Preußischen Minister des Innern. Abwanderung nach Polen

19 III 1922r.: Prezydent rejencji w Marienwerder do ministra spraw wewnętrznych Prus. Odpływ ludności polskiej do Polski

031

23.3.1923: Der Regierungspräsident in Marienwerder an den PreuBischen Minister des Innern. Stellung des Kasimir von Donimirski innerhalb der polnischen Minderheit

23 III 1923r.: Prezydent rejencji w Marienwerder do ministra spraw wewnętrznych Prus. Pozycja Kazimierza Donimirskiego wśród mniejszości polskiej

032

6.4.1926: Der Regierungspräsident in Marienwerder an den PreuBischen Finanzminister. Kreditgenossenschaften im Kreis Stuhm

6 IV 1926r.: Prezydent rejencji w Marienwerder do ministra finansów Prus. Towarzystwa kredytowe w pow. Stuhm

033

1.6.1926: Der Regierungspräsident in Marienwerder an den Oberpräsidenten in Königsberg. Jahreshauptversammlung des Polenbundes in Stuhm (30.5.1926)

1 VI 1926r.: Prezydent rejencji w Marienwerder do naczelnego prezydenta w Königsberg. Walne zebranie roczne Związku Polaków w Stuhm (30 V 1926)

\section{4}

17.9.1929: Der Regierungspräsident in Marienwerder an den Oberpräsidenten in Königsberg. Verstärkte Aktivität der polnischen Minderheit

17 IX 1929r.: Prezydent rejencji w Marienwerder do naczelnego prezydenta w Königsberg. Wzmożona działalność mniejszości polskiej

\section{5}

10.2.1930: Der Regierungspräsident in Marienwerder an den Preußischen Minister des Innern. Polnische Nationalfarben bei einer Beerdigung in Stuhm (2.1.1930)

10 II 1930r.: Prezydent rejencji w Marienwerder do ministra spraw wewnętrznych Prus. Polskie barwy narodowe na pogrzebie w Stuhm (2 I 1930r.)

\section{6}

29.10.1930: Der Regierungspräsident in Marienwerder an den Preußischen Minister des Innern. Zwischenfall in Nikolaiken, Kreis Stuhm (20.10.1930)

29 X 1930r.: Prezydent rejencji w Marienwerder do ministra spraw wewnętrznych Prus. Incydent we wsi Nikolaiken, pow. Stuhm (20 X 1930r.)

037

31.10.1930: Der Regierungspräsident in Marienwerder an den Preußischen Minister des Innern. Telegramm über erneuten Zwischenfall in Nikolaiken, Kreis Stuhm (29./30.10.1930)

31 X 1930r.: Prezydent rejencji w Marienwerder do ministra spraw wewnętrznych Prus. Telegram dot. kolejnego incydentu we wsi Nikolaiken, pow. Stuhm (29/30 X 1930r.) 
1.11.1930: Der Regierungspräsident in Marienwerder an das Auswärtige Amt. Hintergründe des Zwischenfalls in Nikolaiken, Kreis Stuhm (29./30.10.1930)

1 XI 1930r.: Prezydent rejencji w Marienwerder do MSZ. Tło incydentu we wsi Nikolaiken, pow. Stuhm (29/30 X 1930r.)

\section{9}

8.12.1930: Der Regierungspräsident in Marienwerder an den PreuBischen Minister für Wissenschaft, Kunst und Volksbildung. Das polnische Minderheitsschulwesen

8 XII 1930r.: Prezydent rejencji w Marienwerder do pruskiego ministra nauki, sztuki i oświaty ludowej. Szkolnictwo mniejszości polskiej

\section{0}

Anfang 1931: Der Landrat in Stuhm an den Regierungspräsidenten in Marienwerder. Weihnachtsbescherungen in polnischen Vereinen, Schulen und Kindergärten

Początek 1931r.: Landrat w Stuhm do prezydenta rejencji w Marienwerder. Podarki gwiazdkowe w polskich stowarzyszeniach, szkołach i przedszkolach

\section{1}

6.2.1931: Der Polizeipräsident in Elbing an den Regierungspräsidenten in Marienwerder. Tagung des Polenbundes in Stuhm (1.2.1931)

6 II 1931r.: Prezydent policji w Elbing do prezydenta rejencji w Marienwerder. Narada Związku Polaków w Stuhm (1 II 1931r.)

\section{2}

23.7.1931: Der Polizeipräsident in Elbing an den Regierungspräsidenten in Marienwerder. Auswirkungen der Wirtschaftskrise

23 VII 1931r.: Prezydent policji w Elbing do prezydenta rejencji w Marienwerder. Skutki kryzysu gospodarczego

043

10.12.1931: Der Regierungspräsident in Marienwerder an den Preußischen Minister für Wissenschaft, Kunst und Volksbildung. Störung der Predigt des Bischofs von Ermland in Stuhm

10 XII 1931r.: Prezydent rejencji w Marienwerder do pruskiego ministra nauki, sztuki i oświaty ludowej. Zakłócenie kazania biskupa Warmii w Stuhm

044

1.2.1932: Der Regierungspräsident in Marienwerder an den Preußischen Minister des Innern. Beurteilung des „Polnisch-preußischen Bundes"

1 II 1932r.: Prezydent rejencji w Marienwerder do ministra spraw wewnętrznych Prus. Opinia o ,Związku Prusko-Polskim“

045

9.6.1932: Der Polizeipräsident in Elbing an den Regierungspräsidenten in Marienwerder. Kaffeekränzchen des Kingavereins in Nikolaiken, Kreis Stuhm (29.5.1932)

9 VI 1932r: Prezydent policji w Elbing do prezydenta rejencji w Stuhm. Spotkanie towarzyskie Stowarzyszenia św. Kingi we wsi Nikolaiken, pow. Stuhm (29 V 1932r.) 


\section{6}

30.6.1934: Der Regierungspräsident in Marienwerder an den Oberpräsidenten in Königsberg. Empfang des polnischen Konsuls in Marienwerder (3.5.1934)

30 VI 1934r.: Prezydent rejencji w Marienwerder do naczelnego prezydenta w Königsberg. Przyjęcie konsula polskiego w Marienwerder (3 V 1934r.)

\section{7}

19.11.1934: Der Regierungspräsident in Marienwerder an den Oberpräsidenten in Königsberg. Interpretation der Volkszählung von 1933

19 XI 1934r.: Prezydent rejencji w Marienwerder do naczelnego prezydenta w Königsberg. Interpretacja spisu ludności z 1933r.

\section{8}

30.11.1934: Der Regierungspräsident in Marienwerder an den Reichs- und PreuBischen Minister des Innern. Versammlung des Kinga-Vereins in Altmark, Kreis Stuhm (4.11.1934)

30 XI 1934r.: Prezydent rejencji w Marienwerder do ministra spraw wewnętrznych Rzeszy i Prus. Zebranie Stowarzyszenia św. Kingi we wsi Altmark, pow. Stuhm (4 XI 1934r.)

\section{9}

15.4.1935: Staatspolizeistelle Elbing an die Staatspolizeistelle Königsberg. Auswirkungen des deutsch-polnischen Abkommens auf die polnische Minderheit

15 IV 1935r.: Policja placówki państwowej w Elbing do placówki policji państwowej w Königsberg. Wpływ paktu polsko-niemieckiego na mniejszość polską

050

März 1935: Der Regierungspräsident in Marienwerder an den Reichs- und PreuBischen Minister des Innern. Lagebericht

Marzec 1935r.: Prezydent rejencji w Marienwerder do ministra spraw wewnętrznych Rzeszy i Prus. Sprawozdanie sytuacyjne

\section{1}

13.1.1936: Der Regierungspräsident in Marienwerder an den Reichs- und PreuBischen Minister des Innern. Lagebericht

13 I 1936r.: Prezydent rejencji w Marienwerder do ministra spraw wewnętrznych Rzeszy i Prus. Sprawozdanie sytuacyjne

\section{2}

27.3.1920: Wojewodschaft in Torun an die Starosten. Fragenkatalog zur periodischen Lageberichterstattung

27 III 1920r.: Urząd Wojewódzki w Toruniu do starostów. Kwestionariusz dot. periodycznego skladania sprawozdań sytuacyjnych 
053

9.12.1920: Wojewodschaft in Toruń an die Starosten. Berichterstattung über den Deutschtumsbund

9 XII 1920r.: Urząd Wojewódzki w Toruniu do starostów. Sprawozdania z działalności „Deutschtumsbund“

\section{4}

11.2.1922: Amt für öffentliche Sicherheit der Wojewodschaft in Toruń an den Wojewoden ebendort. Lagebericht (Januar 1922)

11 II 1922r.: Wydział Bezpieczeństwa Publicznego Urzędu Wojewódzkiego w Toruniu do Wojewody na miejscu. Sprawozdanie sytuacyjne (styczeń 1922)

\section{5}

11.5.1923: Der Wojewode in Toruń an die Starosten. Aufösung aller Organisationen des Deutschtumsbundes

11 V 1923r.: Wojewoda w Toruniu do starostów. Rozwiązanie wszystkich organizacji Deutschtumsbundu

\section{6}

19.6.1923: Der Wojewode in Toruń an die Starosten. Ungebrochene Aktivität des Deutschtumbundes

19 VI 1923r.: Wojewoda w Toruniu do starostów. Kontynuowanie działalności przez Deutschtumsbund

\section{7}

4.11.1925: Der Wojewode in Toruń an das Innenministerium. Lagebericht für Oktober 1925

4 XI 1925r.: Wojewoda w Toruniu do MSW. Sprawozdanie sytuacyjne za okres październik 1925 r.

\section{8}

23.4.1927: Der Wojewode in Toruń an die Starosten. Richtlinien zur Berichterstattung 23 IV 1927r.: Wojewoda w Toruniu do Starostów. Wytyczne odnośnie do sprawozdań

059

23.4.1927: Der Wojewode in Toruń an die Starosten. Anlegung eines Katasters der deutschen Minderheit

23 IV 1927r.: Wojewoda w Toruniu do Starostów. Zalożenie katastru mniejszości niemieckiej

060

27.8.1931: Wojewodschaft in Torun an die Starosten. Aktualisierung des Katasters der deutschen Minderheit

27 VIII 1931r.: Urząd Wojewódzki w Toruniu do starostów. Aktualizacja katastru mniejszości niemieckiej 


\section{1}

Juli 1932: Wojewodschaft in Toruń an das Innenministerium. Minderheiten-Lagebericht (Juni 1932)

lipiec 1932r.: Urząd Wojewódzki w Toruniu do MSW. Sprawozdanie sytuacyjne dot. mniejszości niemieckiej (czerwiec 1932r.)

062

März 1933: Wojewodschaft in Toruń an das Innenministerium. Minderheiten-Lagebericht (Februar 1933)

Marzec 1933r.: Urząd Wojewódzki w Toruniu do MSW. Sprawozdanie sytuacyjne dot. mniejszości niemieckiej (luty 1933r.)

063

März 1934: Wojewodschaft in Toruń an das Innenministerium. Minderheiten-Lagebericht (Februar 1934)

Marzec 1934r.: Urząd Wojewódzki w Toruniu do MSW. Sprawozdanie sytuacyjne dot. mniejszości niemieckiej (luty 1934r.)

064

März 1935: Wojewodschaft in Toruń an die Starosten. Berichterstattung über den Volkstrauertag der deutschen Minderheit (16.-17.3.1935)

Marzec 1935r.: Urząd Wojewódzki w Toruniu do starostów. Polecenie zlożenie sprawozdań dot. żałoby narodowej mniejszości niemieckiej (16-17 III 1935r.)

065

13.2.1936: Der Wojewode in Toruń an die Starosten. Vorgehen gegen die DV

13 II 1936r.: Wojewoda w Toruniu do starostów. Postępowanie wobec DV

\section{6}

11.8.1936: Wojewodschaft in Toruń an die Starosten. Erlaß des Innenministeriums vom 8.6.1936 über die Vorgehensweise gegen die deutsche Minderheit

11 VIII 1936r.: Urząd Wojewódzki w Toruniu do starostów. Rozporządzenie MSW z dn. 8 VI 1936r. dot. sposobu postępowania wobec mniejszości niemieckiej

067

Oktober 1936: Wojewodschaft in Toruń an das Innenministerium. Minderheiten-Lagebericht (September 1936)

Październik 1936r.: Urząd Wojewódzki w Toruniu do MSW. Sprawozdanie sytuacyjne dot. mniejszości niemieckiej (wrzesień 1936r.)

068

April 1938: Der Wojewode in Toruń an das Innenministerium. Minderheiten-Lagebericht (März 1939)

Kwiecień 1938r.: Wojewoda w Toruniu do MSW. Sprawozdanie sytuacyjne dot. mniejszości niemieckiej (marzec 1938r.) 
069

12.4.1939: Wojewodschaft in Toruń an das Innenministerium. Zwischenfälle der letzten Zeit

12 IV 1939r.: Urząd Wojewódzki w Toruniu do MSW. Incydenty w ostatnim okresie

070

15.4.1939: Wojewodschaft in Toruń an das Innenministerium. Fernschreiben über Zwischenfälle

15 IV 1939r.: Urząd Wojewódzki w Toruniu do MSW. Juzogram dot. zajść

071

Mai 1939: Der Wojewode in Toruń an das Innenministerium. Minderheiten-Lagebericht (April 1939)

Maj 1939r.: Wojewoda w Toruniu do MSW. Sprawozdanie sytuacyjne dot. mniejszości niemieckiej (kwiecień 1939r.)

072

August 1939: Der Wojewode in Toruń an das Innenministerium. Minderheiten-Lagebericht (Juli 1939)

Sierpień 1939r.: Wojewoda w Toruniu do MSW. Sprawozdanie sytuacyjne dot. mniejszości niemieckiej (lipiec 1939r.)

073

18.2.1920: Der Starost in Grudziądz an die Wojewodschaft in Toruń. Festnahme des deutschen Sozialistenführers Gahr aus Grudziądz.

18 II 1920r.: Starosta w Grudziądzu do Urzędu Wojewódzkiego w Toruniu. Aresztowanie Gahra, niemieckiego przywódcy socjalistycznego zam. w Grudziądzu

\section{4}

28.2.1920: Starostei Grudziądz an den Kreis-Polizeikommandanten ebendort. Weiteres Vorgehen gegen den deutschen Sozialistenführer Gahr

28 II 1920r.: Starostwo w Grudziądzu do Komendanta Posterunku Powiatowego w miejscu. Dalsze postępowanie przeciwko Gahrowi, niemieckiemu przywódcy socjalistycznemu

075

13.5.1920: Starostei Grudziądz an die Wojewodschaft in Toruń. Lagebericht

13 V 1920r.: Starostwo w Grudziądzu do Urzędu Wojewódzkiego w Toruniu. Sprawozdanie sytuacyjne

076

14.7.1920: Starostei Grudziądz an die Wojewodschaft in Toruń. Lagebericht

14 VII 1920r.: Starostwo w Grudziądzu do Urzędu Wojewódzkiego w Toruniu. Sprawozdanie sytuacyjne 
077

20.8.1920: Starostei Grudziądz an die Wojewodschaft in Toruń. Lagebericht

20 VIII 1920r.: Starostwo w Grudziądzu do Urzędu Wojewódzkiego w Toruniu. Sprawozdanie sytuacyjne

078

28.2.1928: Staatspolizeikommando Grudziądz an den Starosten ebendort. Deutsche Wahlversammlung in Dusocin (25.2.1928)

28 II 1928r.: Komenda Policji Państwowej w Grudziądzu do Starosty w miejscu. Niemieckie zebranie wyborcze we wsi Dusocin (25 II 1928r.)

079

11.10.1928: Der Starost in Grudziądz an den Wojewoden in Toruń. Wochen-Lagebericht Nr. 41

11 X 1928r.: Starosta w Grudziądzu do Wojewody w Toruniu. Tygodniowe sprawozdanie sytuacyjne nr 41

080

26.10.1932: Ermittlungsabteilung der Staatspolizei in Grudziądz an den Oberbürgermeister ebendort. Schulverhältnisse in Dusocin

26 X 1932r.: Wydział Śledczy Policji Państwowej w Grudziądzu do Starosty Grodzkiego w miejscu. Stosunki szkolne we wsi Dusocin

081

20.11.1934: Der Starost in Grudziądz an die Wojewodschaft in Toruń. Feier des Unabhängigkeitstages in evangelischen Kirchen

20 XI 1934r.: Starosta w Grudziądzu do Urzędu Wojewódzkiego w Toruniu. Uroczystości z okazji Dnia Niepodległości w zborach ewangelickich

082

18.3. 1935: Staatspolizeiposten in Łasin an den Starosten in Grudziądz. Deutsche Heldengedenkfeier (17.3.1935)

18 III 1935r.: Posterunek Policji Państwowej we wsi Łasin do Starosty w Grudziądzu. Obchody niemieckiego Dnia Pamięci Bohaterów (17 III 1935)

083

28.6.1935: Magistrat Radzyń an den Starosten in Grudziądz. Verstärkte Aktivität der deutschen Minderheit

28 VI 1935r.: Zarząd Miejski w Radzynie do Starosty w Grudziądzu. Wzmożona działalność mniejszości niemieckiej

\section{4}

13.7.1920: Starostei in Sępólno Kr. an die Wojewodschaft in Toruń. Lagebericht 13 VII 1920r.: Starostwo w Sępólnie Kr. do Urzędu Wojewódzkiego w Toruniu. Sprawozdanie sytuacyjne 
13.8.1920: Starostei in Sępólno Kr. an die Wojewodschaft in Toruń. Lagebericht 13 VIII 1920r.: Starostwo w Sępólnie Kr. do Urzędu Wojewódzkiego w Toruniu. Sprawozdanie sytuacyjne

\section{6}

1.5.1922: Der Starost in Sępólno Kr. Verzeichnis politisch verdächtigter Personen l V 1922r.: Starosta w Sępólnie Kr. Spis osób politycznie podejrzanych

087

10.8.1922: Der Starost in Sępólno Kr. an den Wojewoden in Toruń. Lagebericht (Juli 1922)

10 VIII 1922r.: Starosta w Sepólnie do Wojewody w Toruniu. Sprawozdanie sytuacyjne (lipiec 1922)

\section{8}

26.3.1923: Kreiskommando der Staatspolizei in Sepólno Kr. an das Bezirkskommando XII der Staatspolizei in Toruń. Deutsche patriotische Lieder auf einer Veranstaltung des Landbundes in Sępólno Kr. (16.1.1923)

26 III 1923r.: Komenda Powiatowa Policji Państwowej w Sępólnie Kr. do Komendy Policji Państwowej Okregu XII w Toruniu. Niemieckie pieśni patriotyczne na zebraniu Landbundu (16 I 1923r.)

\section{9}

26.3.1923: Der Starost in Sępólno Kr. an den Wojewoden in Toruń. Lagebericht (Februar 1923)

26 III 1923r.: Starosta w Sępólnie Kr. do Wojewody w Toruniu. Sprawozdanie sytuacyjne (luty 1923r.)

\section{0}

3.7.1923: Der Starost in Sepólno Kr. an den Wojewoden in Toruń. Lagebericht (Juni 1923)

3 VII 1923r.: Starosta w Sępólnie Kr. do Wojewody w Toruniu. Sprawozdanie sytuacyjne (czerwiec 1923)

\section{1}

2.7.1926: Der Starost in Sępólno Kr. an den Wojewoden in Toruń. Lagebericht (Juni 1926)

2 VII 1926r.: Starosta w Sępólnie Kr. do Wojewody w Toruniu. Sprawozdanie sytuacyjne (czerwiec 1926)

092

3.11.1926: Der Starost in Sępólno Kr. an den Wojewoden in Toruń. Lagebericht (Oktober 1926)

3 XI 1926r.: Starosta w Sępólnie Kr. do Wojewody w Toruniu. Sprawozdanie sytuacyjne (październik 1926) 


\section{3}

21.2.1929: Nachrichten-Dienststelle Nr. 36 in Kamień Pomorski an das Grenzkommissariat ebendort. Antipolnische Betätigung des Bernard Römer aus Dąbrówka-Abbau 21 II 1929r.: Posterunek służby informacyjnej nr 36 w Kamieniu Pomorskim do Komisariatu Straży Granicznej w miejscu. Działalność antypolska Bernarda Römera z miejscowości Dąbrówka-Wybudowanie

094

10.3.1932: Staatspolizeiposten Sępólno Kr. an die Starostei ebendort. Rede des Sejmabgeordneten Graebe aus Bydgoszcz (10.3.1932)

10 III 1932r.: Posterunek Policji Państwowej w Sępólnie Kr. do Starostwa w miejscu. Mowa Graebego, posła do Sejmu z Bydgoszczy (10 III 1932)

\section{5}

16.3.1934: Staatspolizeiposten Sępólno Kr. an den Postenkommandanten ebendort. Verhalten des Lehrers Oberländer in Wiśniewka gegenüber polnischen Kindern

16 III 1934r.: Posterunek Policji Państwowej w Sępólnie Kr. do Komendanta Posterunku Policji Państwowej w miejscu. Zachowanie się nauczyciela Oberländera we wsi Wiśniewka wobec dzieci polskich

\section{6}

8.11.1934: Staatspolizeiposten Kamień Pomorski an die Starostei Sępólno Kr. Entlassung polnischer Arbeiterinnen durch den Landwirt Bernard Burdik in Dąbrówka

8 XI 1934r.: Posterunek Policji Państwowej w Kamieniu Pomorskim do Starosty w Sępólnie Kr. Zwolnienie polskich robotnic przez rolnika Bernarda Burdika we wsi Dąbrówka

\section{7}

5.12.1934: Staatspolizeiposten Wałdowo an den Starosten in Sępólno Kr. Versammlung der DV (3.12.1934)

5 XII 1934r.: Posterunek Policji Państwowej w Wałdowie do Starosty w Sepólnie Kr. Zebranie "DV" (3 XII 1934r.)

\section{8}

18.3.1935: Staatspolizeiposten Wałdowo an den Starosten in Sępólno Kr. Deutsche Heldengedenkfeier (17.3.1935)

18 III 1935r.: Posterunek Policji Państwowej w Wałdowie do Starosty w Sepólnie Kr. Obchody niemieckiego Dnia Pamięci Bohaterów (17 III 1935r.)

099

28.11.1936: Kreiskommando der Staatspolizei in Sepólno Kr. an den Starosten ebendort. Sprengung einer Veranstaltung der DV durch JDP-Anhänger (27.11.1936)

28 XI 1936r.: Komenda Powiatowa Policji Państwowej w Sepólnie Kr. do Starosty w miejscu. Rozbicie zebrania „DV“ przez zwolenników „JDP“ (27 XI 1936r.) 
1.5.1937: Der Starost in Sępólno Kr. an die Wojewodschaft in Toruń. Lagebericht (April 1937)

1 V 1937r.: Starosta w Sępólnie Kr. do Urzędu Wojewódzkiego w Toruniu. Sprawozdanie sytuacyjne (kwiecień 1937)

101

22.11.1937: Staatspolizeiposten Sypniewo an den Starosten in Sępólno Kr. Auswirkungen der Auflösung des deutschen Gesangvereins "Konkordia" in Lubcza

22 XI 1937r.: Posterunek Policji Państwowej w Sypniewie do Starosty w Sępólnie Kr. Następstwa rozwiazania niemieckiego towarzystwa śpiewaczego "Konkordia" w Lubczy

102

10.2.1938: Kreiskommando der Staatspolizei in Sępólno Kr. an den Starosten ebendort. Versammlung des Landbundes Weichselgau in Sepólno Kr. (9.2.1938)

10 Il 1938r.: Komenda Powiatowa Policji Państwowej w Sepólnie Kr. do Starosty w miejscu. Zebranie związku ziemskiego „Weichselgau“ w Sepólnie Kr. (9 II 1938r.)

103

14.3.1938: Kreiskommando der Staatspolizei in Sępólno Kr. an den Starosten ebendort. Deutsche Heldengedenkfeier in Sępólno Kr. (13.3.1938)

14 III 1938r.: Komenda Powiatowa Policji Państwowej w Sępólnie Kr. do Starosty w miejscu. Obchody niemieckiego Dnia Pamięci Bohaterów (13 III 1938r.)

104

18.3.1938: Kreiskommando der Staatspolizei in Sępólno Kr. an den Starosten ebendort. Versammlung der JDP in Sępólno Kr. (15.3.1938)

18 III 1938r.: Komenda Powiatowa Policji Państwowej w Sępólnie Kr. Zebranie „JDP“ w Sępólnie Kr. (15 III 1938r.)

105

7.3.1938: Der Starost in Sępólno Kr. an die Wojewodschaft in Toruń. Schließung deutscher Versammlungsräume

7 III 1938r.: Starosta w Sępólnie Kr. do Urzędu Wojewódzkiego w Toruniu. Zamknięcie niemieckich sal zgromadzeń

106

April 1938: Starostei in Sępólno Kr. an die Wojewodschaft in Toruń. MinderheitenLagebericht (März 1938)

Kwiecień 1938r.: Starostwo w Sępólnie Kr. do Urzędu Wojewódzkiego w Toruniu. Sprawozdanie sytuacyjne dot. mniejszości niemieckiej (marzec 1938r.)

\section{7}

21.4.1938: Der Starost in Sępólno Kr. an die Wojewodschaft in Toruń. Polonisierung der Genossenschaftsmolkerei in Kamień Pomorski

21 IV 1938r.: Starosta w Sępólnie Kr. do Urzędu Wojewódzkiego w Toruniu. Spolszczenie mleczarni spółdzielczej w Kamieniu Pomorskim 


\section{8}

Juni 1938: Starostei in Sępólno Kr. an die Wojewodschaft in Toruń. Minderheiten-Lagebericht (Mai 1938)

Czerwiec 1938r.: Starostwo w Sępólnie Kr. do Urzędu Wojewódzkiego w Toruniu. Sprawozdanie sytuacyjne dot. mniejszości niemieckiej (maj 1938r.)

\section{9}

August 1938: Der Starost in Sępólno Kr. an die Wojewodschaft in Toruń. Minderheiten-Lagebericht (Juli 1938)

Sierpień 1938r.: Starosta w Sępólnie Kr. do Urzędu Wojewódzkiego w Toruniu. Sprawozdanie sytuacyjne dot. mniejszości niemieckiej (lipiec 1938r.)

\section{0}

10.12.1938: Der Starost in Sępólno Kr. an die Wojewodschaft in Toruń. Beurteilung der Konzessionsinhaber für den Alkoholverkauf in nationaler Hinsicht

10 XII 1938r.: Starosta w Sępólnie Kr. do Urzędu Wojewódzkiego w Toruniu. Opinia o posiadaczach koncesji na sprzedaż alkoholu pod względem narodowym

\section{1}

4.1.1939: Kreiskommando der Staatspolizei in Sępólno Kr. an den Starosten ebendort. Festnahme des Landwirts Paweł Weilandt aus Duża Cerkwica wegen antipolnischer Äußerungen

4 I 1939r.: Komenda Powiatowa Policji Państwowej w Sepólnie Kr. do Starosty w miejscu. Aresztowanie Pawła Weilandta, rolnika ze wsi Duża Cerkwica z powodu antypolskich wypowiedzi

\section{2}

16.1.1939: Der Starost in Sępólno Kr. an die Wojewodschaft in Toruń. Beurteilung des Kaufmanns Konrad Bracka aus Więcbork in nationaler Hinsicht

16 I 1939r.: Starosta w Sępólnie Kr. do Urzędu Wojewódzkiego w Toruniu. Opinia o Konradzie Bracka, kupca z Więcborka pod względem narodowym

\section{3}

Februar 1939: Starostei Sępólno Kr. an die Wojewodschaft in Toruń. MinderheitenLagebericht (Januar 1939)

luty 1939r.: Starostwo w Sępólnie Kr. do Urzędu Wojewódzkiego w Toruniu. Sprawozdanie sytuacyjne dot. mniejszości niemieckiej (styczeń 1939r.)

\section{4}

17.03.1939: Kreiskommando der Staatspolizei in Sępólno Kr. an den Starosten ebendort. Stimmung der deutschen Minderheit nach Hitlers Einmarsch in Prag

17 III 1939r.: Komenda Powiatowa Policji Państwowej w Sepólnie Kr. do Starosty w miejscu. Nastroje wśród mniejszości niemieckiej po wkroczeniu Hitlera do Pragi 


\section{5}

Mai 1939: Starostei in Sępólno Kr. an die Wojewodschaft in Toruń. Minderheiten-Lagebericht (April 1939)

Maj 1939r.: Starostwo w Sępólnie Kr. do Urzędu Wojewódzkiego w Toruniu. Sprawozdanie sytuacyjne dot. mniejszości niemieckiej (kwiecień 1939r.)

116

3.8.1939: Der Starost in Sępólno Kr. an die Wojewodschaft in Toruń. Lagebericht (Juli 1939)

3 VIII 1939r.: Starosta w Sępólnie Kr. do Urzędu Wojewódzkiego w Toruniu. Sprawozdanie sytuacyjne (lipiec 1939r.)

117

15.2.1922: Der stellvertretende Oberpräsident in Schneidemühl an das Preußische Ministerium des Innern. Polnische Propaganda und Möglichkeiten ihrer Begegnung 15 II 1922r.: Pełniący obowiązki naczelnego prezydenta w Schneidemühl do MSW Prus. Propaganda polska i możliwości jej zapobiegania

118

24.3.1922: Landeskriminalpolizei in Schneidemühl an das Preußische Ministerium des Innern. Polnische Bewegung in Betsche, Kreis Meseritz

24 III 1922r.: Krajowa policja kryminalna w Schneidemühl do MSW Prus. Ruch polski w Betsche, pow. Meseritz

119

11.4.1922: Landeskriminalpolizei in Schneidemühl an das Preußische Ministerium des Innern. Erschwerung der Abwanderung nach Polen durch polnischen Klerus

11 IV 1922r.: Krajowa policja kryminalna w Schneidemühl do MSW Prus. Utrudnianie migracji do Polski przez kler polski

120

31.7.1922: Der stellvertretende Oberpräsident in Schneidemühl, an das Preußische Ministerium des Innern. Polnische Jugendorganisationen im Kreis Flatow

31 VII 1922r.: Pelniący obowiązki naczelnego prezydenta w Schneidemühl do MSW Prus. Polskie organizacje młodzieżowe w pow. Flatow

121

20.10.1922: Landeskriminalpolizei in Schneidemühl an den Staatskommissar für öffentliche Ordnung. Nationale Verhältnisse in Ortschaften des Kreises Meseritz

20 X 1922r.: Krajowa policja kryminalna w Schneidemühl do komisarza państwowego $\mathrm{d} / \mathrm{s}$ porządku publicznego. Stosunki narodowościowe w miejscowościach pow. Meseritz 
122

22.3.1923: Der Oberpräsident in Schneidemühl an den Preußischen Minister des Innern. Gründung einer Ortsgruppe des Polenbundes in Groß Dammer, Kreis Meseritz (11.3.1923)

22 III 1923r.: Naczelny prezydent w Schneidemühl do ministra spraw wewnętrznych Prus. Założenie oddziału miejscowego Związku Polaków we wsi Groß Dammer, pow. Meseritz (11 III 1923r.)

123

10.1.1925: Der Oberpräsident in Schneidemühl an den Preußischen Minister des Innern. Verhinderung einer polnischen Wahlveranstaltung in Betsche, Kreis Meseritz (24.11.1924)

10 I 1925r.: Naczelny prezydent w Schneidemühl do ministra spraw wewnętrznych Prus. Uniemożliwienie odbycia polskiego wiecu wyborczego w Betsche, pow. Meseritz (24 XI 1924r.)

\section{4}

30.7.1926: Der Oberpräsident in Schneidemühl an den Preußischen Minister des Innern. Polnisches Kinderfest in Zakrzewo, Kreis Flatow (18.7.1926)

30 VII 1926r.: Naczelny prezydent w Schneidemühl do ministra spraw wewnętrznych Prus. Polska zabawa dla dzieci we wsi Zakrzewo, pow. Flatow (18 VII 1926r.)

\section{5}

8.3.1927: Der Oberpräsident in Schneidemühl an den Preußischen Minister des Innern. Fortbildungskurse in Polen für Minderheitsangehörige aus dem Kreis Flatow

8 III 1927r.: Naczelny prezydent w Schneidemühl do ministra spraw wewnętrznych Prus. Kursy dokształcające w Polsce dla członków mniejszości polskiej zamieszkujących w pow. Flatow

\section{6}

17.7.1927: Der Oberpräsident in Schneidemühl an den Preußischen Minister des Innern. Zwischenfall bei einer Fahnenweihe des polnisch-katholischen Jugendvereins in Lugetal, Kreis Flatow (29.6.1927)

17 VII 1927r.: Naczelny prezydent w Schnedemühl do ministra spraw wewnętrznych Prus. Incydent w czasie uroczystości poświęcenia sztandaru polsko-katolickiego stowarzyszenia młodzieżowego we wsi Lugetal, pow. Flatow (29 VI 1927r.)

127

2.9.1927: Der Oberpräsident in Schneidemühl an den Preußischen Minister des Innern. Fahnenweihe des katholischen Jünglingsvereins in Groß Dammer, Kreis Meseritz (7.8.1927)

2 IX 1927r.: Naczelny prezydent w Schneidemühl do ministra spraw wewnętrznych Prus. Poświęcenie sztandaru katolickiego stowarzyszenia młodzieży męskiej we wsi Groß Dammer, pow. Meseritz (7 VIII 1927r.) 
128

18.2.1928: Die Polizeidirektion in Schneidemühl an den Oberpräsidenten ebendort. Überblick über die polnische Bewegung (für 1927)

18 II 1928r.: Dyrekcja policji w Schneidemühl do naczelnego prezydenta w miejscu. Przegląd ruchu polskiego (za rok 1927)

129

8.3.1928: Der Oberpräsident in Schneidemühl an den Preußischen Minister des Innern. Zeigen polnischer Nationalfarben in der Öffentlichkeit

8 III 1928r.: Naczelny prezydent w Schneidemühl do ministra spraw wewnętrznych Prus. Publiczne pokazywanie polskich barw narodowych

130

25.2.1929: Der Oberpräsident in Schneidemühl an den Preußischen Minister des Innern. Überblick über die polnische Bewegung (für 1928)

25 II 1929r: Naczelny prezydent w Schneidemühl do ministra spraw wewnętrznych Prus. Przegląd ruchu polskiego (za rok 1928)

\section{1}

19.6.1929: Der Polizeidirektor in Schneidemühl an den Oberpräsidenten ebendort. Eröffnung der polnischen Minderheitsschule in Groß Dammer, Kreis Meseritz (10.6.1929)

19 VI 1929r.: Dyrektor policji w Schneidemühl do naczelnego prezydenta w miejscu. Otwarcie szkoły mniejszości polskiej we wsi Groß Dammer, pow. Meseritz (10 VI 1929r.)

\section{2}

4.7.1929: Der Oberpräsident in Schneidemühl (z. Zt. Berlin) an den Preußischen Minister des Innern. Übergang deutschen Grundbesitzes an Polen

4 VII 1929r.: Naczelny prezydent w Schneidemühl (obecnie w Berlinie) do pruskiego ministra spraw wewnętrznych. Przejście niemieckiej własności ziemskiej do rąk polskich

\section{3}

16.2.1930: Der Oberpräsident in Schneidemühl an den Preußischen Minister des Innern in Berlin. Überblick über die polnische Bewegung (für 1929)

16 II 1930r.: Naczelny prezydent w Schneidemühl do pruskiego ministra spraw wewnętrznych. Przegląd ruchu polskiego (za rok 1929)

134

17.5.1930: Regierung in Schneidemühl an den Preußischen Minister für Wissenschaft, Kunst und Volksbildung. Verhalten des Schulamtsbewerbers Rilinger in Scharzig, Kreis Meseritz

17 V 1930r.: Rejencja w Schneidemühl do pruskiego ministra nauki, sztuki i oświaty ludowej. Zachowanie się kandydata na nauczyciela Rilingera we wsi Scharzig, pow. Meseritz 


\section{5}

15.9.1930: Der Polizeidirektor in Schneidemühl an den Oberpräsidenten ebendort. Polnische Wahlveranstaltung in Zakrzewo, Kreis Flatow (6.9.1930)

15 IX 1930r.: Dyrektor policji w Schneidemühl do naczelnego prezydenta w miejscu. Polskie zebranie wyborcze we wsi Zakrzewo, pow. Flatow (6 IX 1930r.)

\section{6}

7.1.1932: Der Oberpräsident in Schneidemühl an den Preußischen Minister des Innern in Berlin. Polnische Kulturausstellung in Flatow (5.-13.12.1931)

7 I 1932r.: Naczelny prezydent w Schneidemühl do pruskiego ministra spraw wewnętrznych. Wystawa kultury polskiej w Flatow (5-13 XII 1931r.)

\section{7}

12.12.1932: Der Oberpräsident in Schneidemühl an den Preußischen Minister des Innern. Polnische Stimmen bei den Reichstagswahlen

12 XII 1932r.: Naczelny prezydent w Schneidemühl do pruskiego ministra spraw wewnętrznych. Głosy polskie przy wyborach do Reichstagu

\section{8}

27.1.1933: Der Polizeidirektor in Schneidemühl an den Oberpräsidenten ebendort. Winterfest des polnisch-katholischen Jungmännervereins Glumen in Zakrzewo, Kreis Flatow (22.1.1933)

27 I 1933r.: Dyrektor policji w Schneidemühl do naczelnego prezydenta. Zabawa zimowa polsko- katolickiego Stowarzyszenia młodych mężczyzn ze wsi Glumen we wsi Zakrzewo, pow. Flatow (22 I 1933r.)

\section{9}

12.8.1933: Der Oberpräsident in Schneidemühl an den Preußischen Minister des Innern in Berlin. Zwischenfälle in GroB Dammer, Kreis Meseritz (Juli 1933)

12 VIII 1933r.: Naczelny prezydent $w$ Schneidemühl do pruskiego ministra spraw wewnętrznych. Incydenty we wsi Groß Dammer, pow. Meseritz (lipiec 1933r.)

140

26.11.1934: Der Regierungspräsident in Schneidemühl an den Reichs- und Preußischen Minister des Innern. Interpretation der Volkszählung von 1933

26 XI 1934r.: Prezydent rejencji w Schneidemühl do ministra spraw wewnętrznych Rzeszy i Prus. Interpretacja spisu ludności z 1933r.

31.1.1935: Staatspolizeistelle Schneidemühl an das Geheime Staatspolizeiamt. Überblick über die polnische Bewegung (für 1934)

31 I 1935r.: Placówka policji państwowej w Schneidemühl do urzędu tajnej policji państwowej. Przegląd ruchu polskiego (za 1934r.) 


\section{2}

2.10.1935: Der Regierungspräsident in Schneidemühl an den Reichs- und Preußischen Minister des Innern. Lagebericht (August-September 1935)

2 X 1935r.: Prezydent rejencji w Schneidemühl do ministra spraw wewnętrznych Rzeszy i Prus. Sprawozdanie sytuacyjne (sierpień-wrzesień 1935r.)

\section{3}

7.10.1935: Der Oberpräsident in Berlin (für die Provinzen Brandenburg und Grenzmark Posen-Westpreußen) an den Reichs- und Preußischen Minister des Innern. Lagebericht (August-September 1935)

7 X 1935r.: Naczelny prezydent w Berlinie (dla prowincji Brandenburg i Marchii granicznej Posen-Westpreußen) do ministra spraw wewnętrznych Rzeszy i Prus. Sprawozdanie sytuacyjne (sierpień-wrzesień 1935r.)

\section{4}

18.3.1937: Der Regierungspräsident in Schneidemühl an den Reichs- und Preußischen Minister des Innern. Werbung für polnische Minderheitsschulen

18 IIl 1937r.: Prezydent rejencji w Schneidemühl do ministra spraw wewnętrznych Rzeszy i Prus. Propaganda dla szkól mniejszości polskiej

145

24.3. 1938: Der Regierungspräsident in Schneidemühl an den Landrat in Meseritz. Baulicher Zustand polnischer Minderheitenschulen im Vergleich zur deutschen Minderhcitsschule Neutomischel

24 III 1938r.: Prezydent rejencji w Schneidemühl do landrata w Meseritz. Stan budowli szkolnych mniejszości polskiej w porównaniu do szkoly mniejszości niemieckiej w Nowym Tomyślu

\section{6}

13.4.1938: Der Oberpräsident in Berlin (für die Provinzen Brandenburg und Grenzmark Posen-Westpreußen) an den Reichs- und Preußischen Minister des Innern. Verhalten der Polen bei der Volksabstimmung und Reichstagswahl (10. 4. 1938)

13 IV 1938r.: Naczelny prezydent w Berlinie (dla prowincji Brandenburg i Marchii granicznej Posen-Westpreußen) do ministra spraw wewnętrznych Rzeszy i Prus. Postawa Polaków zamieszkujących w pow. Flatow w czasie plebiscytu i wyborów do Reichstagu (10 IV 1938r.)

\section{7}

27.6.1939: Der Regierungspräsident in Frankfurt/Oder an den Reichsminister für Wissenschaft, Erziehung und Volksbildung. Maßnahmen gegen Lehrer an polnischen Minderheitsschulen

27 VI 1939r.: Prezydent rejencji w Frankfurt/Oder do ministra Rzeszy do spraw nauki, wychowania $\mathrm{i}$ oświaty ludowej. Środki podejmowane przeciwko nauczycielom w szkołach mniejszości polskiej 
148

20.1.1921: Kommissariat Flatow der Landesgrenzpolizei Osten an den Landrat ebendort. Feier der polnischen Arbeiter-Vereinigung in Krojanke (16.1.1921)

20 I 192 lr.: Komisariat krajowej policji granicznej „Wschód“ w Flatow do landrata w miejscu. Uroczystość polskiego stowarzyszenia robotniczego w Krojanke (16 I 1921r.)

149

22.3.1921: Landjäger Adam in Groß Friedrichsberg an den Landrat in Flatow. Gerüchte über eine Angliederung des Restkreises Flatow an Polen

22 III 1921r.: Adam, żandarm we wsi Groß Friedrichsberg do landrata w Flatow. Pogłoski o przyłączeniu do Polski reszty powiatu Flatow

\section{0}

14.4.1921: Dienststelle Kujan der Landeskriminalpolizei an den Landrat in Flatow. Polnische Berufsvereinigung

14 IV 1921r.: Placówka obszaru dworskiego Kujan krajowej policji kryminalnej do landrata w Flatow. Zjednoczenie Zawodowe Polskie

\section{1}

2.1.1922: Der Landrat in Flatow an den Regierungspräsidenten in Schneidemühl. Pfarrer Domański, Zakrzewo

2 I 1922r.: Landrat w Flatow do prezydenta rejencji w Schneidemühl. Ksiądz proboszcz Domański, Zakrzewo

152

6.7.1922: Kommissariat Flatow der Landeskriminalpolizei an den Landrat ebendort. Volksfest der katholischen Gemeinde Zakrzewo (2.7.1922)

6 VII 1922r.: Komisariat krajowej policji kryminalnej w Flatow do landrata w miejscu. Zabawa ludowa parafii katolickiej we wsi Zakrzewo (2 VII 1922r.)

153

5.2.1923: Landjägeramt Wilhelmssee an den Landrat in Flatow. Nichtbeachtung des Trauertages anläßlich der französischen Ruhrgebietsbesetzung durch Pfarrer Paszki, Slawianowo (14.1.1923)

5 II 1923r.: Żandarmeria we wsi Wilhelmssee do landrata w Flatow. Nieprzestrzeganie przez ks. Paszkego dnia żałoby we wsi Slawianowo z powodu francuskiej okupacji zagłębia Ruhry (14 I 1923r.)

\section{4}

26.4.1923: Staatliches Grenzkommissariat Flatow an das leitende Grenzkommissariat in Schneidemühl. Polnische Organisationen

26 IV 1923r.: Państwowy komisariat graniczny w Flatow do naczelnego komisariatu granicznego w Schneidemühl. Organizacje polskie 
155

1.2.1924: Der Landrat in Flatow an den Oberpräsidenten in Schneidemühl. Polnische Jugendvereine in der Stadt Flatow

l II 1924r.: Landrat w Flatow do naczelnego prezydenta w Schneidemühl. Polskie stowarzyszenia młodzieżowe w Flatow

156

5.6.1924: Landjägeramt Lugetal an den Landrat in Flatow. Polnische Nationalfarben während des Besuches des päpstlichen Delegaten (2.6.1924)

5 VI 1924r.: Żandarmeria we wsi Lugetal do landrata w Flatow. Polskie barwy narodowe w czasie wizyty delegata papieskiego (2 VI 1924r.)

\section{7}

22.6.1924: Landjägeramt Radawnitz an den Landrat in Flatow. Polnische Nationalfarben während der Fronleichnamsprozession (19.6.1924)

22 VI 1924r.: Żandarmeria we wsi Radawnitz do landrata w Flatow. Polskie barwy narodowe w czasie procesji Bożego Ciała (19 VI 1924r.)

158

30.10.1925: Der Landrat in Flatow an den Oberpräsidenten in Schneidemühl. Polnische Mitglieder im Reichsbanner Schwarz-Rot-Gold

30 X 1925r.: Landrat w Flatow do naczelnego prezydenta w Schneidemühl. Polscy członkowie organizacji „Reichsbanner Schwarz-Rot-Gold“

159

21.11.1925: Landjägeramt Groß Butzig an den Landrat in Flatow. Geheime polnische Versammlung (17.11.1925)

21 XI 1925r.: Żandarmeria w Groß Butzig do landrata w Flatow. Tajne zebranie polskie (17 XI 1925r.)

160

23.1.1926: Staatliches Grenzkommissariat Flatow an den Landrat ebendort. Jüngste Entwicklung in der polnischen Bewegung

23 I 1926r.: Państwowy komisariat graniczny w Flatow do landrata w miejscu. Najnowsze tendencje w ruchu polskim

161

3.3.1926: Staatliches Grenzkommissariat in Flatow an den Landrat ebendort. Beurteilung des praktischen Arztes Dr. Hugo Schipkowski, Flatow, in nationaler Hinsicht

3 III 1926r.: Państwowy komisariat graniczny w Flatow do landrata w miejscu. Opinia o dr Hugo Schipkowskim, lekarzu praktykującym w Flatow pod względem narodowym

162

3.3.1930: Der Landrat in Flatow an den Oberpräsidenten in Schneidemühl. Verschuldung deutscher Grundbesitzer an die Bank Ludowy

3 III 1930r.: Landrat w Flatow do naczelnego prezydenta w Schneidemühl. Zadłużenie niemieckich właścicieli ziemskich w Banku Ludowym 
163

29.7.1932: Landjägeramt Zakrzewo an den Landrat in Flatow. Zwischenfall vor dem Pfarrhaus (28.7.1932)

29 VII 1932r.: Żandarmeria we wsi Zakrzewo do landrata w Flatow. Zajście przed plebanią (28 VII 1932r.)

\section{4}

7.2.1933: Der Landrat in Flatow an den Oberpräsidenten in Schneidemühl. Finanzielle Mittel für den Erhalt und Ausbau deutschen Grundbesitzes

7 II 1933r.: Landrat w Flatow do naczelnego prezydenta w Schneidemühl. Środki finansowe na rzecz podtrzymania i poszerzenia niemieckiej wlasności ziemskiej

\section{5}

8.2.1933: Der Landrat in Flatow an den Oberpräsidenten in Schneidemühl. Kirchliche Versorgung der Deutschkatholiken in Zakrzewo

8 II 1933r.: Landrat $w$ Flatow do naczelnego prezydenta w Schneidemühl. Opieka duchowna nad Niemcami-katolikami we wsi Zakrzewo

166

21.9.1933: Der kommissarische Landrat in Flatow an den kommissarischen Oberpräsidenten in Schneidemühl. Zwischenfälle in Buschdorf (3.9.1933)

21 IX 1933r:: Komisaryczny landrat w Flatow do komisarycznego prezydenta naczelnego w Schneidemühl. Zajścia we wsi Buschdorf (3 IX 1933r.)

167

25.3.1934: Gendarmerieposten Zakrzewo an den Landrat in Flatow Nationale Verhältnisse in der katholischen Schwesternstation

25 III 1934r.: Posterunek żandarmerii we wsi Zakrzewo do landrata w Flatow. Stosunki narodowe u katolickich sióstr miłosierdzia

\section{8}

16.11.1920: Distriktsamt Betsche an den Landrat in Meseritz. Grundstückstausch polnischer Minderheitsangehöriger mit Deutschen aus Polen

16 XI 1920r.: Urząd dystryktu w Betsche do landrata w Meseritz. Zamiana posesji między członkami mniejszości polskiej i Niemcami z Polski

\section{9}

6.2.1923: Der Landrat in Meseritz an den Regierungspräsidenten in Schneidemühl. Ausweisung polnischer Optanten aus Groß Dammer

6 II 1923r.: Landrat $w$ Meseritz do prezydenta rejencji w Schneidemühl. Wydalenie optantów polskich ze wsi Groß Dammer 
170

16.7.1925: Der Landrat in Meseritz an den Regierungspräsidenten in Schneidemühl. Tauschverhandlungen zwischen polnischen Optanten aus Groß Dammer mit deutschen Optanten in Polen

16 VII 1925r.: Landrat w Meseritz do prezydenta rejencji w Schneidemühl. Pertraktacje dot. wymiany posesji między optantami polskimi ze wsi Groß Dammer i optantami niemieckimi z Polski

\section{1}

18.7.1925: Der Landrat in Meseritz an den Regierungspräsidenten in Schneidemühl. Ermittlung einseitiger polnischer Optanten

18 VII 1925r.: Landrat w Meseritz do prezydenta rejencji w Schneidemühl. Ustalenia polskich optantów

172

29.8.1928: Kriminal- und Grenzkommissariat Stentsch an den staatlichen Polizeidirektor in Schneidemühl. Nationalpolnisches Engagement des Vikars von Styp-Rekowski

29 VIII 1928r.: Komisariat kryminalny i graniczny we wsi Stentsch do państwowego dyrektora policji w Schneidemühl. Narodowo-polska działalność wikarego StypRekowskiego

173

29.8.1928: Kriminal- und Grenzkommissariat Stentsch an den staatlichen Polizeidirektor in Schneidemühl. Polnische Versammlung in Scharzig

29 VIII 1928r.: Komisariat kryminalny i graniczny we wsi Stentsch do państwowego dyrektora policji w Schneidemühi. Zebranie polskie we wsi Scharzig

\section{4}

16.10.1928: Der Landrat in Meseritz an den Oberpräsidenten in Schneidemühl. Ersuchen um Versetzung des Vikars von Styp-Rekowski, Meseritz

16 X 1928r.: Landrat w Meseritz do naczelnego prezydenta w Schneidemühl. Prośba o przeniesienie wikarego Styp-Rekowskiego, zam. w Meseritz

175

22.12.1928: Kriminal- und Grenzkommissariat Stentsch an den staatlichen Polizeidirektor in Schneidemühl. Polnische Organisationen in Groß Dammer

22 XII 1928r.: Komisariat kryminalny i graniczny we wsi Stentsch do państwowego dyrektora policji w Schneidemühl. Organizacje polskie we wsi GroB Dammer

176

6.12.1929: Kriminal- und Grenzkommissariat Stentsch an den staatlichen Polizeidirektor in Schneidemühl. Polnische Versammlung in Scharzig (31.11.1929)

6 XII 1929r.: Komisariat kryminalny i graniczny we wsi Stentsch do państwowego dyrektora policji w Schneidemühl. Zebranie polskie we wsi Scharzig (31 XI 1929r.) 
177

7.2.1931: Kriminal- und Grenzkommissariat Neu Bentschen an den Landrat in Meseritz. Überblick über die polnische Bewegung (für 1930)

7 II 1931r.: Komisariat kryminalny i graniczny w Neu Bentschen do landrata w Meseritz. Przegląd ruchu polskiego (za rok 1930)

178

26.3.1933: Landjägerposten Groß Dammer an den Distriktskommissar in Kuschten. Gemeindewahlen

26 III 1933r.: Posterunek żandarmerii we wsi Groß Dammer do komisarza dystryktu we wsi Kuschten. Wybory gminne

179

Dezember 1933: Landjägerposten Groß Dammer an den Distriktskommissar in Kuschten. Überblick über die polnische Bewegung (für 1933)

Grudzień 1933r.: Posterunek żandarmerii we wsi Groß Dammer do komisarza dystryktu we wsi Kuschten. Przegląd ruchu polskiego (za rok 1933)

180

Januar 1934: Der Schulrat in Meseritz an den Regierungspräsidenten in Schneidemühl. Schulverhältnisse in GroB-Dammer

Styczeń 1934r.: Kurator w Meseritz do prezydenta rejencji w Schneidemühl. Stosunki szkolne we wsi Groß Dammer

\section{1}

5.4.1934: Kriminal- und Grenzkommissariat Neu Bentschen an die Staatspolizeistelle Schneidemühl. Antipolnisches Verhalten der SA in GroB Dammer (1.4.1934)

5 IV 1934r.: Komisariat kryminalny i graniczny w Neu Bentschen do placówki policji państwowej w Schneidemühl. Antypolskie zachowanie sie SA we wsi Groß Dammer (1 IV 1934r.)

\section{2}

15.10.1934: Gendarmerieposten Il Groß Dammer an das Distriktsamt in Kuschten. Festnahme des Landwirts Theodor Pawelski in Polen (7.10.1934)

15 X 1934r.: Posterunek żandarmerii II we wsi Groß Dammer do urzędu dystryktowego we wsi Kuschten. Aresztowanie rolnika Teodora Pawelskiego w Polsce ( 7 X 1934r.)

\section{3}

20.10.1934: Gendarmerieposten II Groß Dammer an das Distriktsamt in Kuschten. Grund der Festnahme des Landwirts Theodor Pawelski in Polen (7.10.1934)

20 X 1934r.: Posterunek żandarmerii II we wsi Groß Dammer do urzędu dystryktowego we wsi Kuschten. Przyczyny aresztowania Teodora Pawelskiego w Polsce (7 X 1934r.)

\section{4}

20.10.1934: Der Distriktskommissar in Kuschten an den Landrat in Meseritz. Grund der Festnahme des Theodor Pawelski in Polen (7.10.1934)

20 X 1934r.: Komisarz dystryktu we wsi Kuschten do landrata w Meseritz. Przyczyny aresztowania Teodora Pawelskiego w Polsce (7 X 1934r.) 


\section{5}

8.4.1935: Kriminal- und Grenzkommissariat Neu Bentschen. Lagebericht

8 IV 1935r.: Komisariat kryminalny i graniczny w Neu Bentschen. Sprawozdanie sytuacyjne

186

23.3.1936: Der Landrat in Meseritz an den Regierungspräsidenten in Schneidemühl. Lagebericht

23 III 1936r.: Landrat w Meseritz do prezydenta rejencji w Schneidemühl. Sprawozdanie sytuacyjne

\section{7}

5.8.1936: Gendarmeriepostenbereich Groß Dammer an den Distriktskommissar zu Kuschten. Polnischer Kindergarten

5 VIII 1936r.: Okręg żandarmerii we wsi Groß Dammer do komisarza dystryktu we wsi Kuschten. Przedszkole polskie

\section{8}

14.12.1936: Gendarmeriepostenbereich Groß Dammer an den Distriktskommissar in Kuschten. Lichtbildervortrag über Gdynia (13.12.1936)

14 XII 1936r.: Okręg żandarmerii we wsi Groß Dammer do komisarza dystryktu we wsi Kuschten. Odczyt z przezroczami na temat Gdyni (13 XII 1936r.)

189

28.1.1937: Gendarmeriepostenbereich Groß Dammer an den Distriktskommissar zu Kuschten. Weihnachtsfeier der polnischen Minderheitsschule

28 I 1937r.: Okreg żandarmerii we wsi Groß Dammer do komisarza dystryktu we wsi Kuschten. Uroczystość Bożego Narodzenia w szkole mniejszości polskiej

190

9.3.1937: Gendarmeriepostenbereich Groß Dammer an den Distriktskommissar in Kuschten. Gastvortrag aus Polen (7.3.1937)

9 III 1937r.: Okręg żandarmerii we wsi Groß Dammer do komisarza dystryktu we wsi Kuschten. Odczyt prelegenta z Polski (7 III 1937r.)

191

19.3.1937: Gendarmeriepostenbericht Groß Dammer an den Distriktskommissar in Kuschten. Beurteilung der Familie des Arbeiters Vinzenz Borowicz, Kutschkau in nationaler Hinsicht

19 III 1937r.: Okręg żandarmerii we wsi Groß Dammer do komisarza dystryktu we wsi Kuschten. Opinia o rodzinie robotnika Wincentego Borowicza, zam. we wsi Kutschkau pod względem narodowym

192

19.4.1937: Gendarmeriepostenbereich Groß Dammer an den Distriktskommissar in Kuschten. Übergriffe gegen deutsche Siedler (17.4.1937)

19 IV 1937r.: Okręg żandarmerii we wsi Groß Dammer do komisarza dystryktu we wsi Kuschten. Nagabywanie kolonistów niemieckich (17 IV 1937r.) 
193

22.6.1937: Gendarmeriepostenbereich Groß Dammer an den Distriktskommissar in Kuschten. Polnische Festveranstaltung (20.6.1937)

22 VI 1937r.: Okręg żandarmerii we wsi Groß Dammer do komisarza dystryktu we wsi Kuschten. Uroczystość polska (20 VI 1937r.)

194

10.7.1937: Der Distriktskommissar in Kuschten an den Landrat in Meseritz. Grenzüberschreitender Besuchsverkehr deutscher und polnischer Vereine

10 VII 1937r.: Komisarz dystryktu we wsi Kuschten do landrata w Meseritz. Ruch przygraniczny stowarzyszeń niemieckich i polskich

\section{5}

23.8.1937: Der Distriktskommissar in Kuschten an das Grenzpolizeikommissariat Neu Bentschen. Pilgerfahrten nach Częstochowa

23 VIII 1937r.: Komisarz dystryktu we wsi Kuschten do komisariatu policji granicznej w Neu Bentschen. Pielgrzymki do Częstochowy

196

20.9.1937: Grenzpolizeikommissariat Neu Bentschen an die Staatspolizeistelle in Frankfurt/Oder. Beurteilung der Brüder Johann und Josef Janusch aus Groß Dammer in nationaler Hinsicht

20 IX 1937r.: Komisariat policji granicznej w Neu Bentschen do placówki policji państwowej w Frankfurt nad Odrą. Opinia o braciach Janie i Józefie Janusch, zam. we wsi Groß Dammer, pod względem narodowym

197

16.11.1937: Der Distriktskommissar in Kuschten an den Landrat in Meseritz. Minderheiten-Lagebericht

16 XI 1937r.: Komisarz dystryktu we wsi Kuschten do landrata w Meseritz. Sprawozdanie sytuacyjne dot. mniejszości polskiej

198

22.11.1937: Der Distriktskommissar in Kuschten an den Landrat in Meseritz. Beurteilung der Konzessionsinhaber aus Groß Dammer in nationaler Hinsicht

22 XI 1937r.: Komisarz dystryktu we wsi Kuschten do landrata w Meseritz. Opinia o koncesjonariuszach ze wsi GroB Dammer pod względem narodowym

199

18.2.1938: Der Distriktskommissar in Kuschten an den Landrat in Meseritz. Minderheiten-Lagebericht

18 II 1938r.: Komisarz dystryktu we wsi Kuschten do landrata w Meseritz. Sprawozdanie sytuacyjne dot. mniejszości polskiej 
11.4.1938: Der Distriktskommissar in Kuschten an den Landrat in Meseritz. Wahlverhalten der polnischen Minderheit in Groß Dammer (10.4.1938)

11 IV 1938r.: Komisarz dystryktu we wsi Kuschten do landrata w Meseritz. Zachowanie się mniejszości polskiej we wsi Groß Dammer w wyborach (10 IV 1938r.) - 11 IV $1938 \mathrm{r}$.

\section{1}

10.5.1938: Der Distriktskommissar in Kuschten an den Landrat in Meseritz. Minderheiten-Lagebericht

10 V 1938r.: Komisarz dystryktu we wsi Kuschten do landrata w Meseritz. Sprawozda. nie sytuacyjne dot. mniejszości polskiej

\section{2}

21.6.1938: Der Distriktskommissar in Kuschten an den Landrat in Meseritz. Genehmigung eines deutschen Schulneubaus in Chodzież im Gegenzug für die Genehmigung eines polnischen Schulneubaus in Groß Dammer

21 VI 1938r.: Komisarz dystryktu we wsi Kuschten do landrata w Meseritz. Zezwolenie na budowe nowej szkoły niemieckiej w Chodzieży w zamian za zezwolenie na budowe nowej szkoły polskiej we wsi Groß Dammer

\section{3}

19.8.1938: Der Distriktskommissar in Kuschten an den Landrat in Meseritz. Minderheiten-Lagebericht

19 VIII 1938r:: Komisarz dystryktu we wsi Kuschten do landrata w Meseritz. Sprawozdanie sytuacyjne dot. mniejszości polskiej

\section{4}

22.8.1938: Der Distriktskommissar in Kuschten an den Landrat in Meseritz. Auswirkung von Festnahmen auf die Stimmung der polnischen Minderheit in Groß Dammer

22 VIII 1938r.: Komisarz dystryktu we wsi Kuschten do landrata w Meseritz. Wpływ aresztowań na nastroje wśród mniejszości polskiej we wsi Groß Dammer

\section{5}

2.11.1938: Der Landrat in Meseritz an den Distriktskommissar in Kuschten. Begutachtung von vier Anträgen auf Kinderbeihilfe aus Groß Dammer

2 XI 1938r.: Landrat w Meseritz do komisarza dystryktu we wsi Kuschten. Ocena wniosków czterech mieszkańców wsi Groß Dammer o zapomogę dziecięca

\section{6}

12.11.1938: Gendarmerie-Hauptwachtmeister Beck in Groß Dammer an den Distriktskommissar in Kuschten. Begutachtung der Kinderbeihilfeanträge

12 XI 1938r.: Główny wachmistrz żandarmerii Beck we wsi Groß Dammer do komisarza dystryktu we wsi Kuschten. Ocena wniosków o zapomogę dziecięca 
23.11.1938: Der Distriktskommissar in Kuschten an den Landrat in Meseritz. Kirchliche Verhältnisse in Groß Dammer

23 XI 1938r.: Komisarz dystryktu we wsi Kuschten do landrata w Meseritz. Stosunki kościelne we wsi Groß Dammer

\section{8}

6.2.1939: Gendarmerieposten I Groß Dammer an das Distriktsamt in Kuschten. Kinderbeihilfen bei Minderheitsangehörigen

6 II 1939r.: Posterunek żandarmerii I we wsi Groß Dammer do urzędu dystryktu we wsi Kuschten. Czlonkowie mnieszości polskiej pobierający zapomogę dziecięcą

209

8.8.1922: Der Wojewode in Poznań an das Innenministerium. Lagebericht (Juli 1922) 8 VIII 1922r.: Wojewoda Poznański do MSW. Sprawozdanie sytuacyjne (lipiec 1922r.)

210

8.12.1922: Der Wojewode in Poznań an das Innenministerium. Lagebericht (November 1922)

8 XII 1922r.: Wojewoda Poznański do MSW. Sprawozdanie sytuacyjne (listopad 1922r.)

\section{1}

9.5.1923: Der Wojewode in Poznań an das Innenministerium. Lagebericht (April 1923) 9 V 1923r.: Wojewoda Poznański do MSW. Sprawozdanie sytuacyjne (kwiecień 1923r.)

\section{2}

10.7.1923: Der Wojewode in Poznań an das Innenministerium. Lagebericht (Juni 1923) 10 VII 1923r.: Wojewoda Poznański do MSW. Sprawozdanie sytuacyjne (czerwiec 1923r.)

\section{3}

11.1.1926: Der Wojewode in Poznań an das Innenministerium. Lagebericht (Dezember 1925)

11 I 1926r.: Wojewoda Poznański do MSW. Sprawozdanie sytuacyjne (grudzień 1925r.)

\section{4}

9.4.1927: Der Wojewode in Poznań an das Innenministerium. Lagebericht (März 1927) 9 IV 1927r.: Wojewoda Poznański do MSW. Sprawozdanie sytuacyjne (marzec 1927r.)

\section{5}

30.8.1927: Der Wojewode in Poznań an die Starosten. Ausarbeitung eines Parzellierungsplanes

30 VIII 1927r.: Wojewoda Poznański do starostów. Opracowanie planu parcelacji 


\section{6}

Februar 1929: Der Wojewode in Poznań an die Starosten. Registrierung deutscher Kinder durch Wanderlehrer

Luty 1929r.: Wojewoda Poznański do starostów. Rejestracja dzieci niemieckich przez nauczycieli wedrownych

\section{7}

10.4.1929: Der Wojewode in Poznań an die Starosten. Kataster der deutschen Minderheit 10 IV 1929r.: Wojewoda Poznański do starostów. Kataster mniejszości niemieckiej

\section{8}

2.1.1931: Der Wojewode in Poznań an den Starosten in Nowy Tomyśl. Beurteilung des Willi Schulz

2 I 1931r.: Wojewoda Poznański do starosty w Nowym Tomyślu. Opinja o Willi Schulzu

219

9.2.1931: Der Wojewode in Poznań an das Innenministerium. Minderheiten-Lagebericht (Januar 1931)

9 II 1931r.: Wojewoda Poznański do MSW. Sprawozdanie sytuacyjne dot. mniejszości niemieckiej (styczeń 1931r.)

220

5.6.1932: Wojewodschaft in Poznań an die Starosten. Ergänzung des Katasters der deutschen Minderheit

5 VI 1932r.: Urząd Wojewódzki Poznaniu do starostów. Uzupełnienie katastru mniejszości niemieckiej

221

14.2.1933: Wojewodschaft in Poznań an das Innenministerium. Minderheiten-Lagebericht (Januar 1933)

14 II 1933r.: Urząd Wojewódzki w Poznaniu do MSW. Sprawozdanie sytuacyjne dot. mniejszości niemieckiej (styczeń 1933r.)

222

30.3.1933: Wojewodschaft in Poznań an die Starosten. Bevollmächtigung des Lehrers Jan Fajtka zur Materialsammlung über nationale Aspekte im Bildungswesen

30 III 1933r.: Urząd Wojewódzki w Poznaniu do starostów. Pełnomocnictwo dla nauczyciela Jana Fajtki do zbierania materiałów na temat aspektów narodowych w oświacie

223

14.6.1933: Wojewodschaft in Poznań an das Innenministerium. Minderheiten-Lagebericht (Mai 1933)

14 VI 1933r.: Urząd Wojewódzki w Poznaniu do MSW. Sprawozdanie sytuacyjne dot. mniejszości niemieckiej (maj 1933r.) 
224

9.2.1934: Wojewodschaft in Poznań an das Innenministerium. Minderheiten-Lagebericht (Januar 1934)

9 II 1934r.: Urząd Wojewódzki w Poznaniu do MSW. Sprawozdanie sytuacyjne dot. mniejszości niemieckiej (styczeń 1934r.)

\section{5}

30.3.1934: Wojewodschaft in Poznań an die Starosten. Verhalten gegenüber der JDP 30 III 1934r.: Urząd Wojewódzki w Pozaniu do starostów. Zachowanie się wobec „JDP“

226

24.8.1936: Wojewodschaft in Poznań an die Starosten. Entlassung polnischer Arbeiter durch deutsche Arbeitgeber

24 VIIl 1936r.: Urząd Wojewódzki w Poznaniu do starostów. Zwolnienie robotników polskich przez pracodawców niemieckich

\section{7}

3.12.1936: Wojewodschaft in Poznań an die Starosten. Kritik der JDP an polnischen Behörden

3 XII 1936r.: Urząd Wojewódzki w Poznaniu do starostów. Krytykowanie władz polskich ze strony ,JDP“

\section{8}

25.3.1937: Wojewodschaft in Poznań an die Starosten. Einstellung der deutschen Minderheit zur Agrarreform

25 III 1937r.: Urząd Wojewódzki w Poznaniu do starostów. Postawa mniejszości niemieckiej wobec reformy agrarnej

\section{9}

13.6.1937: Der Wojewode in Poznań an das Innenministerium. Minderheiten-Lagebericht (Mai 1937) - 12.6.1937

12 VI 1937r.: Wojewoda w Poznański do MSW. Sprawozdanie sytuacyjne dot. mniejszości niemieckiej (maj 1937r.)

\section{0}

November 1938: Der Wojewode in Poznań an das Innenministerium. MinderheitenLagebericht (Oktober 1938)

Listopad 1938r.: Wojewoda Poznański do MSW. Sprawozdanie sytuacyjne dot. mniejszości niemieckiej (październik 1938r.)

231

9.1.1939: Wojewodschaft in Poznań an die Starosten. Durchsuchung der Ortsgruppen der DV

9 I 1939r.: Urząd Wojewódzki w Poznaniu do starostów. Rewizja placówek miejscowych „DV“ 


\section{2}

9.1.1939: Wojewodschaft in Poznań an die Starosten. Aktualisierung des Katasters der deutschen Minderheit

9 I 1939r.: Urząd Wojewódzki w Poznaniu do starostów. Zaktualizowanie katastru mniejszości niemieckiej

233

10.2.1939: Der Wojewode in Poznań an die Starosten. Verhalten gegenüber der JDP 10 Il 1939r.: Wojewoda Poznański do starostów. Wytyczne postępowania wobec „JDP“

\section{4}

30.3.1939: Wojewodschaftskommando der Staatspolizei in Poznań an die Kreiskommandos. Telefonische Anweisung zur Verhinderung antideutscher Ausschreitungen

30 III 1939r.: Komenda Wojewódzka PP w Poznaniu do Komend Powiatowych. Telefonogram dot. zapobiegania zajść antyniemieckich

\section{5}

April 1939: Der Wojewode in Poznań an das Innnenministerium. Minderheiten-Lagebericht (März 1939)

Kwiecień 1939r.: Wojewoda w Poznański do MSW. Sprawozdanie sytuacyjne dot. mniejszości niemieckiej (marzec 1939r.)

\section{6}

22.5.1939: Der Wojewode in Poznań an das Innenministerium. Minderheiten-Lagebericht (April 1939) - 22.5.1939

22 V 1939r.: Wojewoda Poznański do MSW. Sprawozdanie sytuacyjne dot. mniejszości niemieckiej (kwiecień 1939r.)

\section{7}

1.6.1939: Der Wojewode in Poznań an den Starosten in Nowy Tomyśl. Suspendierung und Auflösung deutscher Organisationen

1 VI 1939r.: Wojewoda Poznański do Starosty w Nowym Tomyślu. Zawieszenie i likwidacja organizacji niemieckich

\section{8}

31.7.1939: Wojewodschaft in Poznań an die Starosten. Schließung deutscher Molkereien 31 VIl 1939r.: Urząd Wojewódzki w Poznaniu do starostów. Zamknięcie mleczarni niemieckich

\section{9}

9.8.1939: Der Wojewode in Poznań an das Innennministerium. Minderheiten-Lagebericht (Juli 1939)

9 VIII 1939r.: Wojewoda Poznański do MSW. Sprawozdanie sytuacyjne dot. mniejszości niemieckiej (lipiec 1939r.) 
25.8.1927: Der Starost in Nowy Tomyśl an den Wojewoden in Poznań. Wochen-Lagebericht

25 VIII 1927r.: Starosta w Nowym Tomyślu do Wojewody w Poznaniu. Tygodniowe sprawozdanie sytuacyjne

\section{1}

27.12.1929: Der Starost in Nowy Tomyśl an den Wojewoden in Poznań. Wochen-Lagebericht (20.-26.12.1929)

27 XII 1929r.: Starosta w Nowym Tomyślu do wojewody w Poznaniu. Tygodniowe sprawozdanie sytuacyjne (20-26 XII 1929r.)

\section{2}

Der Amtvorsteher in Miedzichowo an den Starosten in Nowy Tomyśl. Betätigung des ehemaligen deutschen Lehrers Jan Wilhelmi - 3.8.1931

Wójt w Miedzichowie do Starosty w Nowym Tomyślu. Działania Jana Wilhelmiego, byłego nauczyciela niemieckiego - 3 VIII 1931r.

\section{3}

8.10.1931: Der Starost in Nowy Tomyśl an den Wojewoden in Poznań. Auflassungsangelegenheit Fryderyk Schade, Chmielinka

8 X 1931r.: Starosta w Nowym Tomyślu do Wojewody w Poznaniu. Sprawa przewłaszczenia Fryderyka Schade'go, zam. w Chmielince

\section{4}

2.4.1932: Der Starost in Nowy Tomyśl an den Wojewoden in Poznań. MinderheitenLagebericht (März 1932)

2 IV 1932r.: Starosta w Nowym Tomyślu do Wojewody w Poznaniu. Sprawozdanie sytuacyjne dot. mniejszości niemieckiej (marzec 1932r.)

\section{5}

2.5.1932: Der Starost in Nowy Tomyśl an die Wojewodschaft in Poznań. MinderheitenLagebericht (April 1932)

2 V 1932r.: Starosta w Nowym Tomyślu do Urzędu Wojewódzkiego w Poznaniu. Sprawozdanie sytuacyjne dot. mniejszości niemieckiej (kwiecień 1932r.)

246

April 1933: Der Starost in Nowy Tomyśl an die Wojewodschaft in Poznań. Minderheiten-Lagebericht (März 1933)

Kwiecień 1933r.: Starosta w Nowym Tomyślu do Urzędu Wojewódzkiego w Poznaniu. Sprawozdanie sytuacyjne dot. mniejszości niemieckiej (marzec 1933r.)

\section{7}

Mai 1933: Der Starost in Nowy Tomyśl an die Wojewodschaft in Poznań. Minderheiten-Lagebericht (April 1933)

Maj 1933r.: Starosta w Nowym Tomyślu do Urzędu Wojewódzkiego w Poznaniu. Sprawozdanie sytuacyjne dot. mniejszości niemieckiej (kwiecień 1933r.) 
2.10.1933: Der Starost in Nowy Tomyśl an die Wojewodschaft in Poznań. Minderhejten-Lagebericht (September 1933)

2 X 1933r.: Starosta w Nowym Tomyślu do Urzędu Wojewódzkiego w Poznaniu. Sprawozdanie sytuacyjne dot. mniejszości niemieckiej (wrzesień 1933r.)

\section{9}

1933 (?): Der Starost in Nowy Tomyśl. Verzeichnis führender Persönlichkeiten der deutschen Minderheit

1933r. (?): Starosta w Nowym Tomyślu. Wykaz wybitnych działaczy niemieckich 250

7.5.1934: Staatspolizeiposten Zbąszyń an die Starostei Nowy Tomyśl. Gründung einer Ortsgruppe der JDP in Strzyżewo (6.5.34)

7 V 1934r.: Posterunek PP w Zbąszynie do starostwa w Nowym Tomyślu. Założenie placówki miejscowej „JDP“" w Strzyżewie (6 V 1934r.) - 7 V 1934r.

\section{1}

Februar 1935: Der Starost in Nowy Tomyśl an die Wojewodschaft in Poznań. Minderheiten-Lagebericht (Januar 1935)

Luty 1935r.: Starosta w Nowym Tomyślu do Urzędu Wojewódzkiego w Poznaniu. Sprawozdanie sytuacyjne dot. mniejszości niemieckiej (styczeń 1935r.)

\section{2}

Dezember 1935: Der Starost in Nowy Tomyśl an die Wojewodschaft in Poznań. Minderheiten-Lagebericht (November 1935)

Grudzień 1935r.: Starosta w Nowym Tomyślu do Urzędu Wojewódzkiego w Poznaniu. Sprawozdanie sytuacyjne dot. mniejszości niemieckiej (listopad 1935r.)

\section{3}

März 1936: Der Starost in Nowy Tomyśl an die Wojewodschaft in Poznań. Minderheiten-Lagebericht (Februar 1936)

Marzec 1936r.: Starosta Powiatowy w Nowym Tomyślu do Urzędu Wojewódzkiego w Poznaniu. Sprawozdanie sytuacyjne dot. mniejszości niemieckiej (luty 1936)

254

22.5.1936: Der Magistrat in Nowy Tomyśl an den Starosten ebendort. Errichtung einer deutschen Schule

22 V 1936r.: Zarząd Miejski w Nowym Tomyślu do Starosty w miejscu. Założenie szkoły niemieckiej

255

12.9.1936: Kreiskommando der Staatspolizei in Nowy Tomyśl an den Starosten ebendort. Betätigung des Otto Steinke aus Orzeczkowo, Kreis Międzychód als Wanderlehrer 12 IX 1936r.: Komenda Powiatowa PP w Nowym Tomyślu do Starosty w miejscu. Działania Ottona Steinke'go, zam. w Orzeczkowie, pow. międzychodzki, jako nauczyciela wędrownego 
5.12.1936: Gemeindevorstand Miedzichowo an den Starosten in Nowy Tomyśl. Nationale Verhältnisse in Lewiczynek

5 XII 1936r.: Zarząd Gminny w Miedzichowie do Starosty w Nowym Tomyślu. Stosunki narodowościowe w Lewiczynku

257

29.10.1937: Kreiskommando der Staatspolizei in Nowy Tomyśl an den Starosten ebendort. Schulverhältnisse

29 X 1937r.: Komanda Powiatowa Policji Państwowej w Nowym Tomyślu do Starosty w miejscu. Stosunki szkolne

258

5.1.1938: Der Starost in Nowy Tomyśl an die Wojewodschaft in Poznań. Gebrauch deutscher Ortsnamen auf einer JDP-Versammlung in Grodzisk (7.11.1937)

5 I 1938r.: Starosta w Novym Tomyślu do Urzędu Wojewódzkiego w Poznaniu. Posługiwanie się niemieckimi nazwami miejscowymi na zebraniu „JDP“ w Grodzisku (7 XI 1937r.)

\section{9}

1938: Der Starost in Nowy Tomyśl. Verzeichnis führender Persönlichkeiten der deutschen Minderheit

1938r.: Starosta w Nowym Tomyślu. Wykaz wybitnych działaczy niemieckich

260

März 1939: Der Starost in Nowy Tomyśl an die Wojewodschaft in Poznań. Minderheiten-Lagebericht (Februar 1939)

Marzec 1939r.: Starosta w Nowym Tomyślu do Urzędu Wojewódzkiego w Poznaniu. Sprawozdanie sytuacyjne dot. mniejszości niemieckiej (luty 1939r.)

261

8.3.1939: Der Starost in Nowy Tomyśl an den Wojewoden in Poznań. Anträge auf Internierung deutscher Minderheitenführer

8 III 1939r.: Starosta w Nowym Tomyślu do Wojewody w Poznaniu. Wnioski na osadzenie w Miejscu Odosobnienia przewodniczących mniejszości niemieckiej

262

April 1939: Der Starost in Nowy Tomyśl an die Wojewodschaft in Poznań. Minderheiten-Lagebericht (März 1939)

Kwiecień 1939r.: Starosta w Nowym Tomyślu do Urzędu Wojewódzkiego w Poznaniu. Sprawozdanie sytuacyjne dot. mniejszości niemieckiej (marzec 1939r.)

\section{3}

1.4.1939: Der Magistrat in Zbąszyń an den Starosten in Nowy Tomyśl. TagesLagemeldung

1 IV 1939r.: Zarząd Miejski w Zbąszyniu do Starosty w Nowym Tomyślu. Dzienny meldunek sytuacyjny 
264

17.4.1939: Staatspolizeiposten Buk an den Starosten in Nowy Tomyśl. TagesLagemeldung

17 IV 1939r.: Posterunek Policji Państwowej Buk do Starosty w Nowym Tomyślu. Dzienny meldunek sytuacyjny

265

26.4.1939: Staatspolizeiposten Buk an den Starosten in Nowy Tomyśl. TagesLagemeldung

26 IV 1939r.: Posterunek Policji Państwowej Buk do Starosty w Nowym Tomyślu. Dzienny meldunek sytuacyjny

\section{6}

8.5.1939: Gemeindevorstand Miedzichowo an den Starosten in Nowy Tomyśl. Antrag auf Ausweisung von Deutschen aus der Grenzzone

8 V 1939r.: Zarząd Gminny w Miedzichowie do Starosty w Nowym Tomyślu. Wniosek o wydalenie Niemców ze strefy granicznej

267

Mai 1939: Der Starost in Nowy Tomyśl an die Wojewodschaft in Poznań. Minderheiten-Lagebericht (April 1939)

Maj 1939r.: Starosta w Nowym Tomyślu do Urzędu Wojewódzkiego w Poznaniu. Sprawozdanie sytuacyjne dot. mniejszości niemieckiej (kwiecień 1939r.)

\section{8}

2.6.1939: Der Starost in Nowy Tomyśl an die Staatspolizeiposten. Auflösung und Suspendierung deutscher Organisationen

2 VI 1939r.: Starosta w Nowym Tomyślu do Posterunków PP. Likwidacja i zawieszenie organizacji niemieckich

269

5.6.1939: Der Starost in Nowy Tomyśl an den Wojewoden in Poznań. Auflösung und Suspendierung der Tätigkeit deutscher Organisationen (3.6.1939)

5 VI 1939r.: Starosta w Nowym Tomyślu do Wojewody w Poznaniu. Likwidacja i zawieszenie działalności organizacji niemieckich (3 VI 1939r.)

270

Juli 1939: Der Starost in Nowy Tomyśl an die Wojewodschaft in Poznań. Minderheiten-Lagebericht (Juni 1939)

Lipiec 1939r.: Starosta w Nowym Tomyślu do Urzędu Wojewódzkiego w Poznaniu. Sprawozdanie sytuacyjne dot. mniejszości niemieckiej (czerwiec 1939r.)

\section{1}

August 1939: Der Starost in Nowy Tomyśl an die Wojewodschaft in Poznań. Minderheiten-Lagebericht (Juli 1939)

Sierpień 1939r.: Starosta w Nowym Tomyślu do Urzędu Wojewódzkiego w Poznaniu. Sprawozdanie sytuacyjne dot. mniejszości niemieckiej (lipiec 1939r.) 
272

24.8.1939: Der Starost in Nowy Tomyśl an die Wojewodschaft in Poznań. TagesLagemeldung

24 VIII 1939r.: Starosta w Nowym Tomyślu do Urzędu Wojewódzkiego w Poznaniu. Dzienny meldunek sytuacyjny

\section{3}

30.8.1939: Staatspolizeiposten Kuślin an den Starosten in Nowy Tomyśl. TagesLagemeldung

30 VIII 1939r.: Posterunek PP Kuślin do Starosty w Nowym Tomyślu. Dzienny meldunek sytuacyjny

\section{4}

8.12.1923: Der Oberpräsident in Oppeln an den PreuBischen Minister des Innern. Maßnahmen gegen die polnische Minderheitenpresse

8 XII 1923r.: Naczelny prezydent w Oppeln do pruskiego ministra spraw wewnętrznych. Środki przeciw polskiej prasie mniejszościowej

275

23.1.1924: Der Oberpräsident in Oppeln an den PreuBischen Minister des Innern. Bedrohung des Pfarrers Klimas in Tarnau, Kreis Oppeln

23 I 1924r.: Naczelny prezydent w Oppeln do pruskiego ministra spraw wewnętrznych. Groźby wobec proboszcza Klimasa we wsi Tarnau, pow. Oppeln

\section{6}

18.3.1924: Leitendes Grenzkommissariat Oppeln an den Oberpräsidenten ebendort. Unterschriftensammlung für die Errichtung einer polnischen Minderheitsschule in Czarnowanz, Kreis Oppeln

18 III 1924r.: Kierujący komisariat graniczny w Oppeln do naczelnego prezydenta w miejscu. Zbieranie podpisów na rzecz założenia szkoły mniejszości polskiej we wsi Czarnowanz, pow. Oppeln

277

7.5.1925: Leitendes Grenzkommissariat Oppeln an den Oberpräsidenten ebendort. Polnische Agitation des Maurers Franz Buhl aus Grudschütz, Kreis Oppeln

7 V 1925r: Kierujący komisariat graniczny w Oppeln do naczelnego prezydenta w miejscu. Polska agitacja murarza Franza Buhla, zam. we wsi Grudschütz, pow. Oppeln

\section{8}

15.3.1925: Leitendes Grenzkommissariat Oppeln an den Oberpräsidenten ebendort. Minderheitsschule in Gorrek, Kreis Oppeln

13 V 1925r.: Kierujący komisariat graniczny w Oppeln do naczelnego prezydenta w miejscu. Szkoła mniejszości polskiej we wsi Gorrek, pow. Oppeln 
26.9.1925: Der Oberpräsident in Oppeln an den Preußischen Minister des Innern. Bedrohung der polnischen Minderheit

25 IX 1925r.: Naczelny prezydent w Oppeln do pruskiego ministra spraw wewnętrznych. Zagrożenie mniejszości polskiej

\section{0}

1.5.1926: Der Oberpräsident in Oppeln an den Preußischen Minister des Innern. Neuwahl des Vorstandes im Teilverband I des Polenbundes in Oppeln 18.4.1926

1 V 1926r.: Naczelny prezydent w Oppeln do ministra spraw wewnętrznych. Nowo wybrany zarząd dzielnicy I Związku Polaków w Oppeln (18 IV 1926r.)

\section{1}

1.7.1926: Der Oberpräsident in Oppeln an den Preußischen Minister des Innern. Krise innerhalb der polnischen Bewegung

1 VII 1926r.: Naczelny prezydent w Oppeln do pruskiego ministra spraw wewnętrznych. Kryzys w lonie ruchu polskiego

282

17.1.1927: Leitendes Grenzkommissariat Oppeln an den Oberpräsidenten ebendort. Polnische Bewegung im Kreis Oppeln

17 I 1927r.: Kierujący komisariat graniczny w Oppeln do naczelnego prezydenta w miejscu. Ruch polski w powiecie Oppeln

\section{3}

20.4.1928: Der Oberpräsident in Oppeln an die Landräte und Oberbürgermeister. Gewährleistung eines ungestörten Wahlkampfes für die Polnische Volkspartei

20 IV 1928r.: Naczelny prezydent w Oppeln do landratów i nadburmistrzów. Gwarancja swobody kampanii wyborczej dla „Polskiej Partii Ludowej“

284

18.7.1929: Der Oberpräsident in Oppeln an den Preußischen Minister des Innern. Polnische Muttertagsfeier in Oppeln (23.6.1929)

18 VII 1929r.: Naczelny prezydent w Oppeln do pruskiego ministra spraw wewnętrznych. Polska uroczystość z okazji Dnia Matki (23 VI 1929r.)

\section{5}

18.9.1929: Der Oberpräsident in Oppeln an den Preußischen Minister des Innern. Stellungnahme zu Ausführungen auf der polnischen Muttertagsfeier in Oppeln (23.6.1929) 18 IX 1929r.: Naczelny prezydent w Oppeln do pruskiego ministra spraw wewnętrznych. Opinia o wypowiedziach na uroczystości z okazji polskiego Dnia Matki w Oppeln (23 VI 1929r.)

\section{6}

28.9.1929: Der Oberpräsident in Oppeln an den Preußischen Minister des Innern. Personelle Veränderungen an der Spitze der polnischen Bewegung

28 IX 1929r.: Naczelny prezydent w Oppeln do pruskiego ministra spraw wewnętrznych. Zmiany kadrowe $\mathrm{w}$ kierownictwie ruchu polskiego 


\section{7}

15.9.1930: Der Oberpräsident in Oppeln an den Preußischen Minister des Innern. Polnische Stimmen bei der Reichstagswahl (14.9.1930)

15 IX 1930r.: Naczelny prezydent w Oppeln do pruskiego ministra spraw wewnętrznych. Glosowanie Polaków w wyborach do Reichstagu (14 IX 1930r.)

\section{8}

2.5.1931: Der Oberpräsident in Oppeln an den Preußischen Minister des Innern. Gründung des „Bundes der polnischen Oberschlesier“ (6.4.1931)

2 V 1931r.: Naczelny prezydent w Oppeln do pruskiego ministra spraw wewnętrznych. Zalożenie „Związku Górnoślązaków“ w Beuthen (6 IV 1931r.)

\section{9}

13.5.1931: Der Oberpräsident in Oppeln an den Preußischen Minister für Wissenschaft, Kunst und Volksbildung. Polnische Gesangvereine

13 V 1931 r.: Naczelny prezydent w Oppeln do pruskiego ministra nauki, sztuki i oświaty ludowej. Polskie towarzystwa śpiewacze

\section{0}

25.4. 1932: Der Oberpräsident in Oppeln an den Preußischen Minister des Innern. Zwischenfall im Wahlkampf der Polnisch-Katholischen Volkspartei in Klein Kottorz, Kreis Oppeln (23.4.1932)

25 IV 1932r.: Naczelny prezydent w Oppeln do pruskiego ministra spraw wewnętrznych. Incydent w czasie kompanii wyborczej „Polskiej Partii Ludowej“" w Klein Kottorz, pow. Oppeln (23 IV 1932r.)

\section{1}

31.1.1933: Der Oberpräsident in Oppeln an den Preußischen Minister des Innern. Wirtschaftliche Krise in der polnischen Bewegung

31 I 1933r.: Naczelny prezydent w Oppeln do pruskiego ministra spraw wewnętrznych. Kryzys gospodarczy w ruchu polskim

\section{2}

17.3.1933: Der Oberpräsident in Oppeln an den Preußischen Minister des Innern. Die polnische Bewegung seit der Machtergreifung

17 III 1933r.: Naczelny prezydent w Oppeln do pruskiego ministra spraw wewnętrznych. Ruch polski od czasu przyjęcia władzy przez NSDAP

293

14.4.1933: Der Oberpräsident in Oppeln an den Preußischen Minister des Innern. Grundsatzfragen der künftigen Minderheitenpolitik

14 IV 1933r.: Naczelny prezydent w Oppeln do pruskiego ministra spraw wewnętrznych. Zagadnienia podstawowe przyszłej polityki mniejszościowej 
13.9.1934: Der Oberpräsident in Breslau an den Reichs- und PreuBischen Minister des Innern. Lagebericht (August 1934)

13 IX 1934r.: Naczelny prezydent w Breslau do ministra spraw wewnętrznych Rzeszy i Prus. Sprawozdanie sytuacyjne (sierpień 1934r.)

\section{5}

18.3.1935: Der Regierungspräsident in Oppeln an den Reichs- und PreuBischen Minister des Innern. Überblick über die polnische Bewegung (für 1934)

18 III 1935r.: Prezydent rejencji w Oppeln do ministra spraw wewnętrznych Rzeszy i Prus. Przegląd ruchu polskiego (za rok 1934)

\section{6}

9.4.1935: Staatspolizeistelle Oppeln an das Geheime Staatspolizeiamt. Auswirkungen des deutsch-polnischen Abkommens auf die polnische Minderheit

9 IV 1935r.: Placówka policji państwowej w Oppeln do urzędu tajnej policji państwowej. Wpływ paktu polsko-niemieckiego na mniejszość polska

297

7.8.1935: Der Oberpräsident in Breslau an den Reichs- und Preußischen Minister des Innern. Lagebericht

7 VIII 1935r.: Naczelny prezydent w Breslau do ministra spraw wewnętrznych Rzeszy i Prus. Sprawozdanie sytuacyjne

298

9.12.1935: Der Oberpräsident in Breslau an den Reichs- und Preußischen Minister des Innern. Lagebericht

9 XII 1935r.: Naczelny prezydent w Breslau do ministra spraw wewnętrznych Rzeszy i Prus. Sprawozdanie sytuacyjne

299

7.4.1936: Der Oberpräsident in Breslau an die Landräte, Oberbürgermeister und die Staatspolizeistelle Oppeln. Berichterstattung über die polnische Minderheit

7 IV 1936r.: Naczelny prezydent w Breslau do landratów, nadburmistrzów i placówki policji państwowej w Oppeln. Sposób sporządzania sprawozdań o mniejszości polskiej

300

3.8.1936: Der Regierungspräsident in Oppeln an den Reichs- und Preußischen Minister des Innern. Vorgehen gegen polnische Jugendorganisationen

3 VIII 1936r.: Prezydent rejencji w Oppeln do ministra spraw wewnętrznych Rzeszy i Prus. Postępowanie wobec polskich organizacji młodzieżowych

301

27.9.1936: Der Oberpräsident in Oppeln an den Reichs- und PreuBischen Minister des Innern. Interpretation der Volkszählung von 1933

27 IX 1936r.: Naczelny prezydent w Oppeln do ministra spraw wewnętrznych Rzeszy i Prus. Interpretacja spisu ludności z 1933r. 


\section{2}

14.1.1937: Staatspolizeistelle Oppeln an den Landrat ebendort. Beurteilung des Bürgermeisters von Poppelau, Andreas Bautsch, in nationaler Hinsicht

14 I 1937r.: Placówka policji państwowej w Oppeln do landrata w miejscu. Opinia o Andreasie Bautsch, burmistrzu wsi Poppelau pod względem narodowym

303

14.3.1937: Der Oberpräsident in Breslau an die Landräte, Oberbürgermeister, den Polizeipräsidenten in Gleiwitz sowie den Polizeidirektor und die Staatspolizeistelle in Oppeln. Berichterstattung über die polnische Minderheit

14 III 1937r.: Naczelny prezydent w Breslau do landratów, nadburmistrzów, dyrektora policji i placówki policji państwowej w Oppeln. Sposób sporządzania sprawozdań o stanie mniejszości polskiej

\section{4}

22.5.1937: Staatspolizeistelle Oppeln an den Oberpräsidenten ebendort. Katholische Geistliche, die sich zur polnischen Minderheit bekennen oder mit ihr sympathisieren

22 V 1937r.: Placówka policji państwowej w Oppeln do naczelnego prezydenta w miejscu. Duchowni katoliccy przyznający się do mniejszości polskiej lub sympatyzujący $\mathrm{z}$ nia

\section{5}

12.9.1938: Staatspolizeistelle Oppeln an das Geheime Staatspolizeiamt. Festnahme des Arbeiters Roman Golenia aus Beuthen (22.8.1938)

12 IX 1938r.: Placówka policji państwowej w Oppeln do urzędu tajnej policji państwowej. Aresztowanie robotnika Romana Goleni pochodzącego z Beuthen (22 VIII 1938r.)

\section{6}

Februar 1939: Staatspolizeistelle Oppeln an das Geheime Staatspolizeiamt. Tätigkeit des Sekretärs des Polenbundes, Franz Bartsch aus Gruden, Kreis Oppeln

Luty 1939r.: Placówka policji państwowej w Oppeln do urzędu tajnej policji państwowej. Działalność Franciszka Bartscha, sekretarza Związku Polaków ze wsi Gruden, pow. Oppeln

\section{7}

28.2.1939: Der Regierungspräsident in Oppeln an den Reichsminister für Wissenschaft, Erziehung und Volksbildung. Schulische und kirchliche Verhältnisse an Orten mit polnischen Minderheitsschulen

28 II 1939r.: Prezydent rejencji w Oppeln do ministra nauki, wychowania i oświaty publicznej Rzeszy. Stosunki szkolne i kościelne w miejscowościach gdzie istnieja szkoły polskie

\section{8}

22.7.1939: Der Polizeipräsident in Oppeln an den Regierungspräsidenten ebendort. Überblick über die polnische Bewegung (Juli 1939)

22 VII 1939r.: Prezydent policji w Oppeln do prezydenta rejencji w miejscu. Przegląd ruchu polskiego (lipiec 1939r.) 


\section{9}

15.1.1923: Der Amtsvorsteher in Königlich Neudorf an den Landrat in Oppeln. Gerüchte über bevorstehende polnische Erhebung

15 I 1923r.: Wójt we wsi Königlich Neudorf do landrata w Oppeln. Pogłoski o mającym wybuchnąć powstaniu polskim

310

15.4.1923: Landjägeramt Tarnau an den Amtsvorsteher ebendort. Gründung einer Ortsgruppe des Polenbundes in Kossorowitz (14.4.1923)

15 IV 1923r.: Żandarmeria we wsi Tarnau do wójta w miejscu. Założenie miejscowego oddziału Związku Polaków we wsi Kossorowitz (14 IV 1923r.)

\section{1}

13.10.1923: Der Landrat in Oppeln an den Regierungspräsidenten ebendort. Neuformierung der polnischen Bewegung

13 X 1923r.: Landrat w Oppeln do prezydenta rejencji w miejscu. Formowanie sie na nowo ruchu polskiego

312

20.2.1924: Landjägeramt Tarnau an den Amtsvorsteher ebendort. Gründung einer Ortsgruppe der „Freien Vereinigung zum Schutze des Mittelstandes“ (18.2.1924)

20 II 1924r.: Zandarmeria we wsi Tarnau do wójta w miejscu. Założenie miejscowego oddziału „Wolnego Zjednoczenia ku obronie stanu średniego“ (18 II 1924r.)

313

15.6.1925: Der Landrat in Oppeln an den Oberpräsidenten ebendort. Beurteilung des Josef Golletz aus Vogtsdorf in nationaler Hinsicht

15 VI 1925r.: Landrat w Oppeln do naczelnego prezydenta w miejscu. Opinia o Józefie Golletz, zam. we wsi Vogtsdorf pod względem narodowym

314

18.9.1925: Der Amtsvorsteher in Grudschütz an den Landrat in Oppeln. Bedrohung des Polenfühers Franz Buhl

18 IX 1925r.: Wójt we wsi Grudschütz do landrata w Oppeln. Zagrożenie Franciszka Buhla, przywódcy mniejszości polskiej

315

19.5.1926: Der Gemeindevorsteher in Königlich Neudorf an den Landrat in Oppeln. Besuch des polnischen Kommunionsunterrichtes

19 V 1926r.: Sołtys we wsi Königlich Neudorf do landrata w Oppeln. Udział w polskiej katechizacji

5.4.1928: Der Landrat in Oppeln an den Oberpräsidenten ebendort. Kirchliche Verhältnisse in Poppelau

5 IV 1928r.: Landrat w Oppeln do naczelnego prezydenta w miejscu. Stosunki kościelne we wsi Poppelau 
17.12.1928: Der Landrat in Oppeln an den Oberpräsidenten ebendort. Polnische Sportveranstaltung in Grudschütz

17 XII 1928r.: Landrat w Oppeln do naczelnego prezydenta w miejscu. Polska impreza sportowa we wsi Grudschütz

318

5.11.1930: Der Landrat in Oppeln an den Oberpräsidenten ebendor. Handgreiflichkeiten zwischen dem Schiffer Ptok und dem Häusler Gwozdz in Rogau (7.9.1930)

5 XI 1930r.: Landrat w Oppeln do naczelnego prezydenta w miejscu. Rękoczyny pomiędzy żeglarzem Ptokem i chałupnikiem Gwozdz'em we wsi Rogau (7 IX 1930r.)

319

17.3.1931: Der Landrat in Oppeln an den Oberpräsidenten ebendort. Zwischenfälle in Lugnian

17 III 1931r.: Landrat w Oppeln do naczelnego prezydenta w miejscu. Incydenty we wsi Lugnian

320

1.4.1931: Der Landrat in Oppeln an den Oberpräsidenten ebendort. Beurteilung des Pfarrers Pillawa, Bierdzan, in nationaler Hinsicht

I IV 1931r.: Landrat w Oppeln do naczelnego prezydenta w miejscu. Opinia o proboszczu Pillawym ze wsi Bierdzan pod względem narodowym

\section{1}

5.1.1934: Der Landrat in Oppeln an den Regierungspräsidenten ebendort. Überwachung der polnischen Minderheit

5 I 1934r.: Landrat w Oppeln do prezydenta rejencji w miejscu. Nadzór nad mniejszościa polska

322

3.2.1934: Gemeindevorstand Jellowa. Bericht über einen Deutschen Abend (19.11.1933)

3 II 1934r.: Zarząd gminny w Jellowa. Sprawozdanie o wieczorze niemieckim (19 XI 1933r.)

323

31.1.1935: Der Landrat in Oppeln an den Regierungspräsidenten ebendort. Heirat des stellvertretenden Kreisleiters der NSDAP in Oppeln mit der Stieftochter des Polenführers Franz Buhl aus Grudschütz (29.1.1935)

31 I 1935r.: Landrat w Oppeln do prezydenta rejencji w miejscu. Ślub zastępcy kreisleitera NSDAP w Oppeln z pasierbicą Franciszka Buhla, przywódcy mniejszości polskiej (29 I 1935r.)

\section{4}

23.4.1935: Gendarmeriepostenbereich Großdöbern an den Landrat in Oppeln. Polnischer Theaterabend in Kleindöbern (22.4.1935)

23 IV 1935r.: Obręb posterunku żandarmerii Großdöbern do landrata w Oppeln. Polski wieczór teatralny we wsi Kleindöbern (22 IV 1935r.) 
325

Juli 1935: Gendarmerieposten Altschalkowitz an den Landrat in Oppeln. Polnische Festveranstaltung in Neuschalkowitz (7.7.1935)

Lipiec 1935r.: Posterunek żandarmerii we wsi Altschalkowitz do landrata w Oppeln. Polska uroczystość we wsi Neuschalkowitz (7 VII 1935r.)

326

20.1.1936: Der Landrat in Oppeln an den Regierungspräsidenten ebendort. Überblick über die polnische Bewegung (Dezember 1935-Januar 1936)

20 I 1936r.: Landrat w Oppeln do prezydenta rejencji w miejscu. Przegląd ruchu polskiego (grudzień 1935r. - styczeń 1936r.)

327

18.3.1937: Gendarmerie-Hauptwachtmeister Bunke in Nakel an den Amtsvorsteher in Tarnau. Polnische Jugendgruppe in Raschau

18 III 1936r.: Główny wachmistrz żandarmerii Bunke w Nakel do wójta w Tarnau. Polska grupa mlodzieżowa we wsi Raschau

328

3.4.1937: Der Landrat in Oppeln an die Staatspolizeistelle ebendort. Deutsch-polnische Mischehen

3 IV 1937r.: Landrat w Oppeln do placówki policji państwowej w miejscu. Polskoniemieckie małżeństwa mieszane

329

4.9.1937: Der Amtsvorsteher in Tarnau an den Landrat in Oppeln. Beurteilung der Familie Wyrwol in nationaler Hinsicht

4 IX 1937r.: Wójt w Tarnau do landrata w Oppeln. Opinia o rodzinie Wyrwolów pod względem narodowym

330

30.9.1937: Der Amtsvorsteher in Ehrenfeld an den Landrat in Oppeln. Nationale Verhältnisse in Kreuzwalde

30 IX 1937r.: Wójt w Ehrenfeld do landrata w Oppeln. Stosunki narodowościowe we wsi Kreuzwalde

331

8.12.1937: Der Amtsvorsteher in Eichtal an den Landrat in Oppeln. Nationale Spannungen im Gottesdienst

8 XII 1937r.: Wójt w Eichtal do landrata w Oppeln. Napięcia na tle narodowościowym w czasie nabożeństw

332

6.2.1938: Der Amtsvorsteher in Birkental an den Landrat in Oppeln. Überblick über die polnische Bewegung und Möglichkeiten ihrer Bekämpfung

6 II 1938r.: Wójt w Birkental do landrata w Oppeln. Przegląd ruchu polskiego i możliwości jego zwalczania 
333

9.7.1938: Der Amtsvorsteher in Birkental an den Landrat in Oppeln. Überblick über die polnische Bewegung

9 VII 1938r.: Wójt w Birkental do landrata w Oppeln. Przegląd ruchu polskiego

334

12.8.1938: Der Landrat in Oppeln an den Regierungspräsidenten ebendort. Probleme einer statistischen Erfassung der polnischen Minderheit

12 VIII 1938r.: Landrat w Oppeln do prezydenta rejencji w miejscu. Problemy ujęcia statystycznego mniejszości polskiej

335

8.10.1938: Der Amtsvorsteher in Birkental an den Landrat in Oppeln. Überblick über die polnische Bewegung

8 X 1938r.: Wójt w Birkental do landrata w Oppeln. Przegląd ruchu polskiego

336

13.1.1939: Der Amtsvorsteher in Vogtsdorf an den Landrat in Oppeln. KarteimäBige Erfassung der polnischen Minderheit

13 I 1939r.: Wójt w Vogtsdorf do landrata w Oppeln. Ujęcie mniejszości polskiej w kartotece

337

2.5.1939: Der Amtsvorsteher in Vogtsdorf an den Landrat in Oppeln. Antipolnische Ausschreitungen in Vogtsdorf (28/29.4.1939)

2 V 1939r.: Wójt w Vogtsdorf do landrata w Oppeln. Ekscesy antypolskie we wsi Vogtsdorf (28/29 IV 1939r.)

\section{8}

8.5.1939: Der Amtsvorsteher in Döbern an den Landrat in Oppeln. Überblick über die polnische Bewegung

8 V 1939r.: Wojt w Döbern do landrata w Oppeln. Przegląd ruchu polskiego

339

23.5.1939: Der Amtsvorsteher in Birkental an den Landrat in Oppeln. Ausweisung des polnischen Minderheitsangehörigen Knosalla aus Oberschlesien

23 V 1939r.: Wójt w Birkental do landrata w Oppeln. Wydalenie z Górnego Śląska Knosally członka mniejszości polskiej

\section{0}

12.7.1939: Der Amtsvorsteher in Bolko an den Landrat in Oppeln. Aufhebung polnischer Gottesdienste (1.-2.7.1939)

12 VII 1939r.: Wójt w Bolko do landrata w Oppeln. Zniesienie nabożeństw polskich (1-2 VII 1939r.) 
341

6.8.1939: Gendarmerieposten Malapane an den Landrat in Oppeln. Einschlagen von Fensterscheiben bei einem Angehörigen der polnischen Minderheit in Koben (5./6.8.1939) 6 VIII 1939r.: Posterunek zandarmerii w Malapane do landrata w Oppeln. Wybicie szyb we wsi Koben u czlonka mniejszości polskiej (5/6 VIII 1939r.)

342

4.7.1924: Der Polizeipräsident in Gleiwitz an den Oberpräsidenten in Oppeln. Verhalten des Pfarrers Jaglo aus Gleiwitz bei einer Bittprozession in Ellguth-Zabrze (25.5.1924)

4 VII 1924r.: Prezydent policji w Gleiwitz do naczelnego prezydenta w Oppeln. Zachowanie się księdza Jaglo z Gleiwitz w czasie procesji błagalnej w Ellguth-Zabrze (25 V 1924r.)

343

14.7.1928: Der Polizeipräsident in Gleiwitz an den Regierungspräsidenten in Oppeln. Zurückdrängung des Einflusses polnischer Gesangvereine

14 VII 1928r.: Prezydent policji w Gleiwitz do prezydenta rejencji w Oppeln. Zmniejszenie wpływu polskich kółek śpiewaczych

344

5.1.1929: Der Polizeipräsident in Gleiwitz an den Oberpräsidenten in Oppeln. Lagebericht (September - Dezember 1928)

5 I 1929r.: Prezydent policji w Gleiwitz do naczelnego prezydenta w Oppeln. Sprawozdanie sytuacyjne (za wrzesień-grudzień 1928r.)

345

27.3.1929: Der Polizeipräsident in Gleiwitz an den Oberpräsidenten in Oppeln. Weihnachtsfeiern in polnischen Minderheitsschulen

27 III 1929r.: Prezydent policji w Gleiwitz do naczelnego prezydenta w Oppeln. Uroczystości Bożego Narodzenia w szkołach mniejszości polskiej

\section{6}

14.3.1936: Der Polizeipräsident in Gleiwitz an den Regierungspräsidenten in Oppeln. Lagebericht (15.1.-14.3.1936)

14 III 1936r.: Prezydent policji w Gleiwitz do prezydenta rejencji w Oppeln. Sprawozdanie sytuacyjne (15 I - 14 III 1936r.)

28.4.1936: Der Oberbürgermeister in Gleiwitz an den Oberpräsidenten in Breslau. Überblick über die polnische Bewegung

28 IV 1936r.: Nadburmistrz w Gleiwitz do naczelnego prezydenta w Breslau. Przegląd ruchu polskiego

\section{8}

12.4.1938: Der Polizeipräsident in Gleiwitz an den Regierungspräsidenten in Oppeln. Minderheiten-Lagebericht (15.3.-10.4.1938) - 12.4.1938

12 IV 1938r.: Prezydent policji w Gleiwitz do prezydenta rejencji w Oppeln. Sprawozdanie sytuacyjne dot. mniejszości polskiej (15 III - 10 IV 1938r.) 
17.8.1939: Der Polizeipräsident in Gleiwitz an den Regierungspräsidenten in Oppeln. Minderheiten-Lagebericht (16.7,-15.8.1939)

17 VIII 1939r.: Prezydent policji w Gleiwitz do prezydenta rejencji w Oppeln. Sprawozdanie sytuacyjne dot. mniejszości polskiej (16 VII - 15 VIII 1939r.)

\section{0}

21.8.1939: Der Landrat in Gleiwitz an den Regierungspräsidenten in Oppeln. Minderheiten-Lagebericht

21 VIII 1939r.: Landrat w Gleiwitz do prezydenta rejencji w Oppeln. Sprawozdanie sytuacyjne dot. mniejszości polskiej

6.9.1923: Oberkommando der Schlesischen Polizei in Katowice an die Wojewodschaft ebendort. Zusammenstöße in Królewska Huta (4.9.1923)

6 IX 1923r.: Glówna Komenda Policji Województwa Śląskiego w Katowicach do Województwa w miejscu. Konflikty w Królewskiej Hucie (4 IX 1923r.)

352

5.3.1924: Wojewodschaft in Katowice an die Starosten und Polizeidirektoren. Reaktionen auf Verhaftungen in Deutsch-Oberschlesien

5 III 1924r.: Urząd Wojewódzki w Katowicach do Starostów i Dyrektorów Policji. Reakcja na aresztowania na niemieckim Górnym Śląsku

353

22.2.1925: Wojewodschaft in Katowice an die Starosten und Polizeidirektoren. Überwachung deutscher Propagandaschriften

22 II 1925r.: Urząd Wojewódzki w Katowicach do Starostów i Dyrektorów Policji. Nadzór nad niemieckimi pismami propagandowymi

354

3.3.1925: Oberkommando der Schlesischen Polizei in Katowice an die Kreiskomandos. Polizeibeamte, deren Ehefrauen dem Deutschen Volksbund angehören

3 III 1925r.: Główna Komenda Policji Województwa Śląskiego w Katowicach do Powiatowych Komend. Funkcjonariusze policji, których żony należą do Niemieckiego Volksbundu

\section{5}

17.12.1925: Oberkommando der Schlesischen Polizei in Katowice an die Kreiskommandos. Teilnahme evangelischer Polizeibeamter am Gottesdienst

17 XII 1925r.: Główna Komenda Policji Województwa Śląskiego w Katowicach do Powiatowych Komend Powiatowych. Uczestnictwo protestanckich funkcjonariuszy policji w nabożeństwach 
356

8.2.1927: Oberkommando der Schlesischen Polizei in Katowice an die Wojewodschaft ebendort. Lagebericht (Januar 1927)

8 II 1927r.: Glówna Komenda Policji Województwa Śląskiego w Katowicach do Urzędu Wojewódzkiego w miejscu. Sprawozdanie sytuacyjne (styczeń 1927 r.)

357

20.5.1927: Wojewodschaft in Katowice an das Innenministerium. Wochen-Lagebericht $(12 .-18.5 .1927)$

20 V 1927r.: Urząd Wojewódzki w Katowicach do MSW. Tygodniowe sprawozdanie sytuacyjne (12-18 V 1927r.)

\section{8}

16.12.1927: Wojewodschaft in Katowice an das Innenministerium. Wochen-Lagebericht (8.-14.12.1927)

16 XII 1927r.: Urząd Wojewódzki w Katowicach do MSW. Tygodniowe sprawozdanie sytuacyjne (8-14 XII 1927r.)

\section{9}

15.12.1928: Wojewodschaft in Katowice an das Innenministerium. Wochen-Lagebericht 15 XII 1928r.: Urząd Wojewódzki w Katowicach do MSW. Tygodniowe sprawozdanie sytuacyjne

\section{0}

9.11.1929: Wojewodschaft in Katowice an das Innenministerium. Lagebericht

9 XI 1929r.: Urząd Wojewódzki w Katowicach do MSW. Sprawozdanie sytuacyjne

\section{1}

5.4.1930: Wojewodschaft in Katowice an das Innenministerium. Minderheiten-Lagebericht (März 1930)

5 IV 1930r.: Urząd Wojewódzki w Katowicach do MSW. Sprawozdanie sytuacyjna dot. mniejszości niemieckiej (marzec 1930r.)

362

18.8.1932: Oberkommando der Schlesischen Polizei in Katowice an die Kreiskommandos. Sympathiebekundungen für den Nationalsozialismus

18 VIIl 1932r.: Glówna Komenda Policji Województwa Śląskiego w Katowicach do Powiatowych Komend Powiatowych. Demonstrowanie sympatii dla narodowego socjalizmu

\section{3}

8.4.1933: Wojewodschaft in Katowice an das Innenministerium. Minderheiten-Lagebericht (März 1933)

8 IV 1933r.: Urząd Wojewódzki w Katowicach do MSW. Sprawozdanie sytuacyjne dot. mniejszości niemieckiej (marzec 1933r.) 


\section{4}

25.9.1933: Wojewodschaft in Katowice an die Starosten un Polizeidirektoren. Verstärkte Aktivitäten der deutschen Minderheit

25 IX 1933r.: Urząd Wojewódzki w Katowicach do Starostów i Dyrektorów Policji. Wzmożona aktywność mniejszości niemieckiej

\section{5}

25.11.1933: Wojewodschaft in Katowice an die Starosten und Polizeidirektoren. Winterhilfsaktion des Deutschen Volksbunds

25 XI 1933r.: Urząd Wojewódzki w Katowicach do Starostów i Dyrektorów Policji. Akcja pomocy zimowej Volksbundu

\section{6}

März 1934: Wojewodschaft in Katowice an das Innenministerium. Minderheiten-Lagebericht (Februar 1934)

Marzec 1934r.: Urząd Wojewódzki w Katowicach do MSW. Sprawozdanie sytuacyjne dot. mniejszości niemieckiej (luty 1934)

5.5.1934: Wojewodschaft in Katowice an die Starosten und Polizeidirektoren. Intensivierung der deutschen Jugendarbeit

5 V 1934r.: Urząd Wojewódzki w Katowicach do Starostów i Dyrektorów Policji. Intensyfikacja pracy mniejszości niemieckiej nad młodzieżą

368

26.1.1935: Wojewodschaft in Katowice an die Starosten und Polizeidirektoren. Kampagne der JDP gegen den Deutschen Volksbund

26 I 1935r.: Urząd Wojewódzki w Katowicach do Starostów i Dyrektorów Policji. Kampania „JDP" przeciwko Niemieckiemu Volksbundowi

369

28.3.1936: Polizeidirektion Katowice an die Wojewodschaft ebendort. Jugendabend des Deutschen Volksbundes in Siemianowice (25.3.1936)

28 III 1936r.: Dyrekcja Policji w Katowicach do Urzędu Wojewódzkiego w miejscu. Wieczór młodzieżowy Niemieckiego Volksbundu w Siemianowicach (25 III 1936r.)

370

8.6.1936: Wojewodschaft in Katowice an das Innenministerium. Minderheiten-Lagebericht (Mai 1936)

8 VI 1936r.: Urząd Wojewódzki w Katowicach do MSW. Sprawozdanie sytuacyjne dot. mniejszości niemieckiej (maj 1936r.)

371

9.10.1936: Wojewodschaft in Katowice an das Innenministerium. Minderheiten-Lagebericht (September 1936)

9 X 1936r:: Urząd Wojewódzki w Katowicach do MSW. Sprawozdanie sytuacyjne dot. mniejszości niemieckiej (wrzesień 1936) 
372

9.12.1937: Wojewodschaft in Katowice an das Innenministerium. Minderheiten-Lagebericht (November 1937)

9 XII 1937r.: Urząd Wojewódzki w Katowicach do MSW. Sprawozdanie sytuacyjne dot. mniejszości niemieckiej (listopad 1937r.)

373

10.5.1938: Wojewodschaft in Katowice an das Innenministerium. Minderheiten-Lage. bericht (April 1938)

10 V 1938r.: Urząd Wojewódzki w Katowicach do MSW. Sprawozdanie sytuacyjne dot mniejszści niemieckiej (kwiecień 1938r.)

374

9.10.1938: Wojewodschaft in Katowice an das Innenministerium. Minderheiten-Lagebericht (September 1938)

9 X 1938r.: Urzad Wojewódzki w Katowicach do MSW. Sprawozdanie sytuacyjne dot mniejszości niemieckiej (wrzesień 1938r.)

375

April 1939: Wojewodschaft in Katowice an das Innenministerium. Minderheiten-Lagebericht (März 1939)

Kwiecień 1939r.: Urząd Wojewódzki w Katowicach do MSW. Sprawozdanie sytuacyjne dot. mniejszości niemieckiej (marzec 1939r.)

376

7.7.1939: Wojewodschaft in Katowice an das Innenministerium. Minderheiten-Lagebe. richt (Juni 1939)

7 VII 1939r.: Urząd Wojewódzki w Katowicach do MSW. Sprawozdanie sytuacyjnz dot. mniejszości niemieckiej (czerwiec 1939r.)

377

5.9.1923: Kommissariat I in Królewska Huta an das Staatskommando der Schlesischea Polizei ebendort. Zwischenfall anläßlich einer deutschen Theatervorstellung (4.9.1923)

5 IX 1923r.: Komisariat I Królewska Huta w Królewskiej Hucie do Miejskiej Komendy Policji Województwa Śląskiego w miejscu. Incydent związany z niemieckim przedstawieniem teatralnym (4 IX 1923r.)

\section{8}

20.12.1923: Polizeidirektion Katowice an die Wojewodschaft ebendort. Verhältnis zw:schen deutscher und polnischer Bevölkerung

20 XII 1923r.: Dyrekcja Policji w Katowicach do Urzędu Wojewódzkiego w miejscu. Stosunki pomiędzy ludnością polską i niemiecką

\section{9}

16.11.1928: Polizeidirektion Królewska Huta an die Wojewodschaft in Katowice. De deutsche Minderheitenpresse und ihre Redakteure

16 XI 1928r.: Dyrekcja Policji Królewska Huta w Królewskiej Hucie do Urzędu Wojewódzkiego w Katowicach. Prasa mniejszości niemieckiej i jej redaktorzy 
6.11.1930: Kreiskommando der Schlesischen Polizei in Tarnowskie Góry an den Staatsanwalt beim Bezirksgericht ebendort. Deutsche Wahlkampfmethoden

6 XI 1930r.: Komenda Powiatowa Policji Województwa Ślaskiego w Tarnowskich Górach do Prokuratora przy Sądzie Okręgowym w miejscu. Sposoby prowadzenia walki wyborczej przez Niemców

381

17.4.1934: Kommissariat Nowa Wieś an das Stadt-und Kreiskommando der Schlesischen Polizei in Katowice. Bunter Abend des Deutschen Volksbunds (16.4.1934)

17 IV 1934r.: Komisariat Nowa Wieś do Miejskiej i Powiatowej Komendy Policji Województwa Śląskiego w Katowicach. Wieczorek towarzyski Niemieckiego Volksbundu (16 IV 1934r.)

382

Kommissariat Siemianowice Śląskie an das Stadt- und Kreiskommando der Schlesischen Polizei in Katowice. Private deutsche Schulkinderspeisung - 25.10.1934

Komisariat Siemianowice Ślaskie do Miejskiej i Powiatowej Komendy Policji Województwa Śląskiego w Katowicach. Dożywianie dzieci w niemieckich szkołach przez osoby prywatne -25 X 1934r.

383

13.2.1935: Stadtkommando Chorzów an die Polizeidirektion ebendort. Kampagne der JDP gegen den Deutschen Volksbund

13 Il 1935r.: Komenda miasta Chorzowa Policji Województwa Śląskiego do Dyrekcji Policji w miejscu. Kampania JDP przeciwko Volksbundowi

384

19.6.1935: Polizeidirektion Chorzów an die Wojewodschaft in Katowice. Bezirksversammlung der JDP in Chorzów I (16.6.1935)

19 VI 1935r.: Dyrekcja Policji w Chorzowie do Urzędu Wojewódzkjego w Katowicach. Zebranie okregowe JDP w Chorzowie I (16 VI 1935r.)

385

5.8.1935: Stadt- und Kreiskommando der Schlesischen Polizei in Katowice an die Polizeidirektion ebendort. Gartenfest des Deutschen Volksbundes in Makoszowy (4.8.1935) 5 VIII 1935: Miejska i Powiatowa Komenda Policji Województwa Śląskiego w Katowicach do Dyrekcji Policji w miejscu. Festyn ogrodowy Volksbundu w Makoszowach (4 VIII 1935r.)

\section{6}

23.8.1935: Polizeidirektion Chorzów an die Wojewodschaft in Katowice. Wahlverhalten der deutschen Minderheit

23 VIII 1935r.: Dyrekcja Policji w Chorzowie do Urzędu Wojewódzkiego w Katowicach. Zachowanie się mniejszości niemieckiej wobec wyborów 
387

9.12.1937: Polizeidirektion Chorzów an die Wojewodschaft in Katowice. Wahlversammlung der Christlichen Deutschen Volkspartei in Chorzów (4.12.1937)

9 XII 1937r.: Dyrekcja Policji w Chorzowie do Urzędu Wojewódzkiego w Katowicach. Zebranie wyborcze stronnictwa Deutsche Christliche Volkspartei w Chorzowie (4 XII 1937r.)

\section{8}

14.3.1938: Polizeidirektion Chorzów an die Wojewodschaft in Katowice. Überblick über Organisationsformem und Besitzstand der einzelnen Nationalitäten

14 III 1938r.: Dyrekcja Policji w Chorzowie do Urzędu Wojewódzkiego w Katowicach. Przegląd form organizacyjnych i stanu majątkowego poszczególnych narodowości 